Spring 2020

\title{
A Win Win: College Athletes Get Paid for Their Names, Images, and Likenesses and Colleges Maintain the Primacy of Academics
}

Jayma Meyer

Andrew S. Zimbalist

Smith College, azimbali@smith.edu

Follow this and additional works at: https://scholarworks.smith.edu/eco_facpubs

Part of the Economics Commons

\section{Recommended Citation}

Meyer, Jayma and Zimbalist, Andrew S., "A Win Win: College Athletes Get Paid for Their Names, Images, and Likenesses and Colleges Maintain the Primacy of Academics" (2020). Economics: Faculty Publications, Smith College, Northampton, MA.

https://scholarworks.smith.edu/eco_facpubs/53

This Article has been accepted for inclusion in Economics: Faculty Publications by an authorized administrator of Smith ScholarWorks. For more information, please contact scholarworks@smith.edu 


\title{
A Win Win: College Athletes Get Paid for Their Names, Images, and Likenesses and Colleges Maintain the Primacy of Academics
}

\author{
Jayma Meyer* and Andrew Zimbalist**
}

\section{ABSTRACT}

California Governor Gavin Newsom signed the Fair Pay to Play Act (SB 206) into law on September 30, 2019. The bill made it illegal for California's universities to prohibit college athletes from receiving compensation for use of their Names, Images, and Likenesses ("NILs"). Lawmakers soon introduced similar bills in other states ${ }^{1}$ and in Congress. ${ }^{2}$

The National Collegiate Athletic Association ("NCAA") lobbied vigorously against SB 206 after its introduction in the California state legislature, threatening to prohibit all of the state's fifty-eight member colleges

* Counsel, Simpson Thacher \& Bartlett LLP and Visiting Clinical Professor of Sports Law, O'Neill School of Public and Environmental Affairs, Indiana University, Bloomington, IN, USA.

** Robert A. Woods Professor of Economics, Smith College, Northampton, MA, USA.

The authors thank Loren Shokes and David Balme for their outstanding research assistance and Donna Lopiano and the editors of JSEL for their helpful comments on an earlier draft of this article. Further, we thank the editors of the JSEL for their editorial support.

1 Through March 2020, thirty-six states have introduced similar bills to the one passed in California. See Matt Norlander, Fair Pay to Play Act: States Bucking NCAA to Let Athletes be Paid For Name, Image, Likeness, CBS Sports (Oct. 3, 2019, 5:43 PM), https://www.cbssports.com/college-football/news/fair-pay-to-play-act-statesbucking-ncaa-to-let-athletes-be-paid-for-name-image-likeness/ [https://perma.cc/ 66SE-6G68].

${ }^{2}$ See infra note 13; Future of College Sports: Government's Role in Athletic Pay, THE AsPen InSTITUTE (Dec. 17, 2019), https://www.aspeninstitute.org/events/future-ofcollege-sports-governments-role-in-athlete-pay/ [https://perma.cc/8Y3F-ZX2J]. 
from postseason play if the bill went into effect at the specified date in 2023. The NCAA also threatened to sue to block the $l_{a w}^{3}$ based on the Commerce Clause of the U.S. Constitution, ${ }^{4}$ which prohibits states from enacting legislation that unduly impacts commerce beyond its borders. ${ }^{5}$

The Fair Pay to Play Act collides with the NCAA's long-time insistence that college athletes be amateurs and thus not receive pay for playing or their athleticism. ${ }^{6}$ Indeed, payments to college athletes for NILs could blow up its amateurism model, which prohibits athletes, unlike other students, from receiving pay for activities including signing endorsements, permitting video games to use their likeness, sponsoring athletic camps, selling jerseys and other apparel, and monetizing social media.

Confronted with snowballing legislation and lawsuits, along with a growing public consensus that the status quo exploits high-profile college athletes, the NCAA sought to regain control by forming a nineteen-member committee to examine the feasibility of NIL payments to student-athletes ("NIL Committee").

After California passed SB 206, the NIL Committee gave the NCAA Board of Governors ("Board") an interim report that tentatively greenlit NIL benefits for athletes but also recommended myriad guidelines and restrictions. Specifically, on October 29, 2019, the Board announced that it had voted to allow athletes generally to receive NIL benefits "in a manner

3 Jon Brodkin, NCAA Fights California Over New Law That Helps Atbletes Get Paid, Ars Technica (Sept. 30, 2019), https://arstechnica.com/tech-policy/2019/09/ ncaa-athletes-could-be-paid-for-being-in-video-games-under-new-calif-law/ [https:/ /perma.cc/3UWP-28CF].

${ }^{4}$ U.S. CONST. art. I, $\$ 8, \mathrm{cl} .3$.

5 In National Collegiate Athletic Ass'n v. Miller, 795 F. Supp. 1476 (D. Nev. 1992), Nevada enacted a statute that would have "impose[d] certain minimum 'due process' procedural standards on the NCAA when the NCAA is investigating a Nevada NCAA member institution." Id. at 1483. Although the court found that the statute did "not facially or directly discriminate against interstate commerce," it held that the statute was unconstitutional under the Commerce Clause because it impaired the contractual relationship between the NCAA and its Nevada member institutions. $I d$.

6 A fundamental tenet of the NCAA is the "principle of amateurism" which, under the NCAA's bylaws, is the theory that "[s]tudent-athletes shall be amateurs in an intercollegiate sport, and their participation should be motivated primarily by education and by the physical, mental and social benefits to be derived. Student participation in intercollegiate athletics is an avocation, and student-athletes should be protected from exploitation by professional and commercial enterprises." NAT'L Collegiate Athletic Ass'n Academic and Membership Affairs Staff, 2019-20 NCAA Division I MANUAL 92.9 (2019) [hereinafter Division I MANuAL]. 
consistent with the collegiate model" NCAA's three Divisions ${ }^{8}$ draw up plans for implementation by January 2021.

Part of the NCAA's concern with SB 206 and other state initiatives around NIL payments is that it would be unworkable to have a national organization with rules and regulations that differ on a state-by-state basis. Indeed, the bills introduced in the South Carolina and New York state legislatures allow for schools to pay athletes directly, ${ }^{9}$ while SB 206 allows schools to make NIL payments to current students (not prospective students) and for payments from third parties. ${ }^{10}$ The New York bill also stipulates that fifteen percent of a school's athletic department revenues go to pay for its student athletes. ${ }^{11}$ Florida's NIL bill would go into effect on July 1, 2021, much earlier than other states. ${ }^{12}$ Fortunately, the prospect of a patchwork of varying state laws appears unlikely to eventuate because Representa-

7 See Nat'l Collegiate Athletic Ass'n, Report of the nCAA Board of Governors OCTOBER 29, 2019 MeETING 4 (2019) [hereinafter NCAA NIL REPORT], https://ncaaorg.s3.amazonaws.com/committees/ncaa/exec_boardgov/

Oct2019BOG_Report.pdf [https://perma.cc/R3CF-J8UQ].

8 The NCAA's three divisions are Division I, Division II and Division III. Our Three Divisions, Nat'l Collegiate Athletic Ass'N, https://www.ncaa.org/sites/ default/files/18-00037\%20NCAA\%20101\%20-

$\%$ 20Our\%20Three\%20Divisions\%20Updates\%20_WEB.pdf [https://perma.cc/ 3CYW-SGR3]; see Divisional Differences and the History of Multidivision Classification, Nat'l Collegiate Athletic Ass'n, http://www.ncaa.org/about/who-we-are/membership/divisional-differences-and-history-multidivision-classification [https:// perma.cc/78FM-E7J2] (explaining the differences between the NCAA's three divisions).

9 See Jenna West, South Carolina Lawmakers to File Proposal Similar to California's Fair Pay to Play Act, Sports Illustrated (Sept. 13, 2019), https://www.si.com/ college/2019/09/13/south-carolina-proposal-pay-college-athletes-fair-pay-play-act [https://perma.cc/652W-XUSC]; Joseph Nardone, New York Senator Proposes Bill To Have College Atbletes Paid Directly By Schools, Forbes (Sept. 18, 2019, 4:28 PM), https://www.forbes.com/sites/josephnardone/2019/09/18/new-york-senator-proposes-bill-to-have-college-athletes-paid-directly-by-schools/\#415a854a4d17 [https:/ /perma.cc/XHT9-ZBX6]. Cf., Colorado SB-123 signed on March 20, 2020, prohibiting schools from paying current or prospective athletes for NILS. SB20-123, 2020 Reg. Sess. (Colo 2020), https://leg.colorado.gov/bills/sb20-123.

${ }^{10} \mathrm{~J}$. Brady McCollough, News Analysis: What's Next for NCAA and College Athletics Now That SB 206 Is Law?, L.A. Times (Sept. 30, 2019, 5:40 PM), https:// www.latimes.com/sports/story/2019-09-30/what-next-for-ncaa-college-athleticsnow-that-sb-206-is-law [https://perma.cc/EXC8-VH6J].

${ }^{11}$ Nardone, supra note 9.

12 See, e.g., Florida Gov. Endorses Proposed NIL Bill That Would Take Effect in '20, SPORTs Bus. J. (Oct. 24, 2019), https://www.sportsbusinessdaily.com/Daily/Issues/ 2019/10/24/Colleges/Florida-NIL.aspx [https://perma.cc/6JLX-FXWY]. 
tive Mark Walker, R-North Carolina, has introduced a NIL bill in the U.S. House of Representatives that would create a uniform federal system. ${ }^{13}$ Similarly, Senators Chris Murphy, D-Connecticut, Mitt Romney, R-Utah, and Marco Rubio, R-Florida, have discussed introducing a NIL bill in the U.S. Senate and the Senate's Commerce Committee held a hearing on the matter in February 2020. ${ }^{14}$

In this Article, we explain the history and role of amateurism in college athletics (Part I); the legal landscape of amateurism and paying college athletes, including NIL payments (Part II); the potential scope of NIL payments (Part III); and the NCAA NIL Committee's recommendations (Part IV). We conclude by offering a public policy proposal for implementing circumscribed NIL rights for college athletes (Part V).

\section{The History of Amateurism ${ }^{15}$}

\section{A. The Evolution of Amateurism}

Whether amateurism rules are necessary for intercollegiate athletics has been the subject of longstanding academic debate and legal challenges. It is instructive to follow the evolution of the NCAA's definition of amateurism from its origins, at which time it prohibited all financial aid based on athletic ability, to its current stance, in which it embraces athletic scholarships and benefits with values generally exceeding those afforded non-athletes.

The NCAA, in its early days, did not enforce many of its policies, rendering definitions and principles of amateurism inconsequential. Article VI of the NCAA's 1906 bylaws burdened each member institution with enforcing violations of its amateurism principles, such as "the offering of

\footnotetext{
13 Student-Athlete Equity Act, H.R. 1804, 116th Cong. (2019).

${ }^{14}$ Alex Daugherty \& Brian Murphy, Marco Rubio Leads Senate Effort to Compensate College Athletes, TAmPa Bay Times (Nov. 8, 2019), https://www.tampabay.com/florida-politics/buzz/2019/11/09/marco-rubio-leads-charge-to-compensate-college-athletes/ [https://perma.cc/FN2S-76AT]. Also, U.S. Representative and former Ohio State football player, Anthony Gonzalez, announced a plan to propose a federal law to allow college athletes the opportunity to earn a profit from endorsements. Dan Murphy, Congressman to Propose Federal Legislation for Paying College Atbletes, ESPN (Oct. 2, 2019), https://www.espn.com/college-sports/story/_/id/27751454/congressman-propose-federal-legislation-paying-college-athletes [https://perma.cc/8Y9GPGES].

15 Portions of this section are based on one of the author's previous work. See Gerald Gurney, Donna A. Lopiano \& Andrew Zimbalist, Unwinding Madness: What Went Wrong With College Sports and How to Fix It 13-15 (2017).
} 
inducements to players to enter colleges or universities because of their athletic abilities or maintaining players while students on account of their athletic abilities."16 Thus, athletic scholarships, as we know them today, violated amateurism rules of the time, while need-based financial aid unrelated to athletics did not.

Not until 1916 did the NCAA define the term "amateurism." Article $\mathrm{VI}(\mathrm{b})$ of the bylaws at that time provided that an amateur is "one who participates in competitive physical sports only for the pleasure, and the physical, mental, moral, and social benefits derived therefrom." ${ }^{17}$ The NCAA amended this definition in 1922: "An amateur sportsman is one who engages in sport solely for the physical, mental, or social benefits he derives therefrom, and to whom the sport is nothing more than an avocation." 18

Because the NCAA had no enforcement power during this time, its members ignored and violated these amateurism rules with impunity. Indeed, a 1929 Carnegie Foundation report on intercollegiate athletics found that three-quarters of the 112 colleges investigated had violated the NCAA's amateurism code and principles. ${ }^{19}$ After declining during the Depression and much of World War II, college sports' commercialization accelerated as the war ended. At the end of 1946, the sports editor of the New York Herald Tribune wrote:

When it comes to chicanery, double-dealing, and undercover work behind the scenes, big-time college football is in a class by itself . . . Should the Carnegie Foundation launch an investigation of college football right now, the mild breaches of etiquette uncovered [in the 1920s] . . would assume a remote innocence which would only cause snickers among the post-war pirates of $1946 .^{20}$

The de facto payrolls of several college teams reached $\$ 100,000$ and the football coach at Oklahoma State estimated that its rival Oklahoma annually spent over $\$ 200,000$ (\$2.86 million in today's dollars) on players. ${ }^{21}$

16 Proceedings of the First Annual Convention of the National Collegiate Athletic Association 22 (Dec. 29, 1906).

17 Proceedings of the Eleventh Annual Convention of the National Collegiate Athletic Association 118 (Dec. 28, 1916).

18 Proceedings of the Seventeenth Annual Convention of the National Collegiate Athletic Association 118 (Dec. 29, 1922).

19 Gurney ET AL., supra note 15, at 12.

20 Murray Sperber, Onward to Victory: The Creation of Modern College SPORTS 168 (1998).

21 ANDREW Zimbalist, UnPAid Professionals: COMMERCIALISM AND CONFLICT in Big-Time College Sports 9 (1999). 
After the situation had gotten sufficiently out of control, the NCAA finally attempted both to ratify the reality of financial aid to athletes and to enforce its code of amateurism. ${ }^{22}$ First, in 1948, the NCAA passed its socalled "Sanity Code," allowing schools to award athletically-related financial aid if the student-athlete qualified for need and the aid was limited to tuition and incidental expenses. Aid exceeding tuition could be granted if it stemmed from superior academic scholarship. In 1950, however, the NCAA effectively abandoned the Sanity Code-which also prohibited schools from withdrawing aid if a student quit participating in athletics - when its membership voted not to expel violating schools. ${ }^{23}$

In 1956, the NCAA finally addressed allowable non-need-based compensation to athletes when it permitted athletic scholarships to cover commonly accepted educational expenses. In 1957, an "Official Interpretation" defined such expenses to include costs for room, board, tuition, books, fees, and $\$ 15$ a month for "laundry money," ${ }^{24}$ equal to $\$ 140$ a month, or $\$ 1,680$ annually, in today's dollars. Few who attended the NCAA's first convention in 1906 could have conceived that, by 1957, NCAA rules would allow a university to use these types of financial inducements to recruit high school athletes. $^{25}$

22 Arguably, this effort began at the 1939 NCAA Convention when the Association passed a rule enabling athletes to receive financial aid based on need, but the aid could not be conditioned on athletic participation. Hence, in principle, it was not a form of athletic aid, rather it was need-based aid that could be allocated to all students, including athletes.

23 Nat'l Collegiate Athletic Ass'n, 1947-48 Yearbook 212-13.

24 Nat'l Collegiate Athletic Ass'N, 1956-57 Yearbook 4-5. It is notable that in its 1957 rules the NCAA did not prohibit payment to athletes for appearances and endorsements. This prohibition did not come until 1964. Of course, the amount of money available for athlete NILs at the time was diminutive. See Roger Noll, Collusion in College Sports: Edward O'Bannon, et al. v. NCAA, et al., in THE Antitrust Revolution: Economics, Competition, And Policy (John Kwoka \& Lawrence White eds., 7th ed. 2018); Corrected Direct and Rebuttal Testimony of Dr. Roger G. Noll to Reflect Final Trial Exhibit Numbers, In re NCAA Athletic Grant-in-Aid Cap Antitrust Litig., 311 F.R.D. 532 (N.D. Cal. 2015) (No. 4:14md-02541).

25 Walter Byers, the executive director of the NCAA from 1951 to 1987 , has characterized the awarding of athletic scholarships as the beginning of a nationwide money laundering scheme whereby boosters who formerly gave money directly to athletes could now funnel it to athletes through legitimate university channels. See Walter Byers, Unsportsmanlike Conduct: Exploiting College Athletes 73 (1995). Significantly, the schools in the Ivy League do not permit scholarships for athletic participation. Prospective Athlete Information, Ivy LEaGue, https:// ivyleague.com/sports/2017/7/28/information-psa-index.aspx [https://perma.cc/ $8 \mathrm{X} 3 \mathrm{H}-\mathrm{DWLH}$. 
The 1957 NCAA rules contained provisions specifically meant to counter a possible argument that athletic scholarships constituted "pay for play," which would have exposed its members to workers' compensation claims and social security contributions. Financial aid could not be "reduced (gradated) or canceled on the basis of an athlete's contribution to team success, injury, or decision not to participate." ${ }^{26}$ Adding form to substance, the NCAA mandated the use of the term "student-athlete." 27

Then, in 1967, the NCAA drifted further from its original amateurism concept in its response to member-school complaints about athletes who accepted four-year scholarships then decided against participating. One athletic director opined that this was "morally wrong," adding that "regardless of what anyone says, this is a contract and it is a two-way street." 28 In response, the NCAA passed rules that allowed the immediate cancelation of an athlete's scholarship should he or she voluntarily withdraw from sports or fail to follow a coach's directives.

The NCAA departed still further from its model of amateurism in 1973 by requiring schools to replace athletic scholarships' four-year guarantees with annually renewable terms, effectively empowering coaches to discontinue scholarships for virtually any reason, including injury, performance, fit, or availability of more favorable talent. ${ }^{29}$ The contingent contractual nature of this relationship and the control it gave to the coaches over the players' behavior had many trappings of an employment contract. ${ }^{30}$

${ }^{26}$ BYers, supra note 25, at 69.

${ }^{27}$ Id. at 75.

${ }^{28}$ Letter from Clyde Smith to Walter Byers (July 6, 1964), in Walter Byers Papers, Long Range Planning Folder, NCAA Headquarter, Overland Park, KANSAS, 163-64.

${ }^{29}$ Id. at 164.

30 Robert A. McCormick \& Amy Christian McCormack, The Myth of the Student Athlete: The College Athlete as Employee, 81 WASH. L. Rev. 71 (2006). Further control was afforded by the longstanding rule that required any athlete changing schools to sit out a year of competition once enrolling at the new school. This rule, dating back to the NCAA's original constitution in 1906, was intended to deter the use of tramp athletes, i.e., athletes who were not matriculated students and were paid under the table to play for school teams. With an exception in a few sports, the rule was still in place as of March 20, 2020 and enforces an asymmetry wherein coaches can jump from school to school without a year of ineligibility but athletes cannot. For transfer terms, see Transfer Terms, Nat'L Collegiate Athletic Ass'N, http:// www.ncaa.org/student-athletes/current/transfer-terms [https://perma.cc/2EGNTQAF]. Athletes who do not like playing for a coach or who are not playing as regularly as they would likely face the penalty of a year's ineligibility if they choose to transfer to a new school. Of course, on some occasions the athlete may want to 


\section{B. The Modern Treatment of Amateurism}

In response to cries of athlete exploitation and an increasing amount of litigation brought under antitrust and labor laws, the NCAA has sought to tweak its treatment of amateurism in recent years to provide athletes with more protection and expanded benefits. In 2012, for example, the NCAA approved a new rule giving Division I schools the option to award multiyear scholarships. ${ }^{31}$ In 2014, the Association started allowing expanded food service for athletes, beyond that available to non-athlete students. ${ }^{32}$ More significantly, in 2015, for Division I, the NCAA began allowing four-year scholarships and cost of attendance ("COA") stipends to the traditional grant-in-aid that covered only the cost of tuition, room and board fees, and required books. ${ }^{33}$ The COA stipends aimed to cover items like cost of transportation to and from school, recommended books, and other items that vary from school to school and are set by each school's maximum financial package, but athletes could use the cash payments however they pleased. ${ }^{34}$ Depending on the school, the COA stipends, as dictated by the application of federal guidelines, vary, equaling between $\$ 2,000$ and $\$ 6,000 .^{35}$ For low

transfer due to an issue with the academic program and would face a similar disincentive.

31 See Michelle Brutlag Hosick, Multiyear Scholarship Rule Narrowly Upheld, Nat'l Collegiate Athletic Ass'N (Feb. 17, 2012, 12:00 AM), http://www.ncaa.org/ about/resources/media-center/news/multiyear-scholarship-rule-narrowly-upheld [https://perma.cc/83R8-EPF5].

32 This tweak was widely seen to gain public support when a star University of Connecticut basketball player very publicly asserted that he went to bed hungry every night. Rodger Sherman, Shabazz Napier: 'There's Hungry Nights Where I'm Not Able To Eat', SB Nation (Apr. 7, 2014, 7:23 PM), https://www.sbnation.com/college-basketball/2014/4/7/5591774/shabazz-napier-uconn-basketball-hungry-nights [https://perma.cc/CYV7-T3CS]; see Zach Schonbrun, N.C.A.A Ensures Athletes Will Get All They Can Eat, N.Y. Times (Apr. 24, 2014), https://www.nytimes.com/2014/ 04/25/sports/ncaa-ensures-athletes-will-get-all-they-can-eat.html [https://perma.cc/ 3AZT-6662].

33 These COA stipends are basically a reincarnation of the so-called laundry money, which was ended in 1973.

${ }^{34}$ Given that there are no controls on how the money is spent or even that it be related to education, there are reports that athletes use the COA money to buy things like video games and hoverboards. See Nina Mandell, Jokes About NCAA Athletes Buying Hoverboards Show That College Sports Still Have A Big Problem, For THE WIN USA Today (Dec. 10, 2015, 9:11 AM), https://ftw.usatoday.com/2015/12/jokesabout-ncaa-athletes-buying-hoverboards-show-that-college-sports-still-have-a-bigproblem [https://perma.cc/R9E6-3BND].

3520 U.S.C. $\$ 1087-1$ (2018). 
income athletes, these newly allowed COA stipends can supplement Pell Grants, ${ }^{36}$ which amounted to $\$ 6,195$ in 2019-20. ${ }^{37}$

The NCAA has permitted many other modifications to its amateurism rules aimed at particular sports or at individual athletes' situations-particularly successful athletes. For example, it permits athletes who win Olympic medals to receive cash prizes from the United States Olympic \& Paralympic Committee under a program called Operation Gold. ${ }^{38}$ The amount has increased over the years; today, gold medalists receive $\$ 37,500$, silver medalists $\$ 22,500$, and bronze medalists $\$ 15,000$, while team members split the prize money equally. ${ }^{39}$ The NCAA also permits tennis players to receive up

36 Federal Pell Grants are awarded to low income undergraduate students with exceptional financial need. Unlike a loan, federal Pell Grants do not have to be repaid. The maximum grant awarded for the 2019-2020 academic year is $\$ 6,195$ and the amount recipients are awarded vary depending upon their contribution, attendance costs, whether they are full or part time students and if they plan to be enrolled in school for the full academic year. See Federal Pell Grants, Federal STUDent Aid - An Office of the U.S. Department of Education, https:// studentaid.ed.gov/sa/types/grants-scholarships/pell [https://perma.cc/5TRH-ATB5].

37 Kevin Allen, Here Are Some Benefits NCAA Atbletes Already Are Eligible For That You Might Not Know About, USA Today (Oct. 1, 2019, 4:06 PM), https:// www.usatoday.com/story/sports/college/2019/10/01/ncaa-football-basketball-benefits-college-athletes-now-can-receive/2439120001/ [https://perma.cc/S8UU5VGV]; see O’Bannon v. Nat'l Collegiate Athletic Ass'n, 7 F. Supp. 3d. 955, 974 (N.D. Cal. 2014).

38 See Steve Berkowitz, Olympic Swimmer Joseph Schooling Scores Big In Butterfly With \$740,000 In Win Over Phelps, USA Today (Aug. 13, 2016, 6:14 AM), https:// www.usatoday.com/story/sports/olympics/rio-2016/2016/08/12/singapore-olympicswimming-texas-ncaa-cash-bonuses-butterfly/88647594/ [https://perma.cc/Q3HVT77B].

39 The NCAA also permits college athletes to receive awards for medaling in world championships and foreign swimmers to receive what their respective countries award them. For example, the NCAA permitted a swimmer at the University of Texas to accept $\$ 740,000$ from Singapore, the country for which he competed at the Rio 2016 Olympic Games. See Berkowitz, supra note 38. Given this paper's focus on athlete publicity rights, it is noteworthy that in October 2019, the United States Olympic and Paralympic Committee ("USOPC") announced that it would interpret the IOC's Rule 40 (that does not allow athletes to publicize any endorsement agreements with companies they may have during the Olympic Games) to allow athletes to publicize their corporate ties in most circumstances as long as the company in question first registered with the USOPC. The traditional IOC concern with such situations (often referred to as "ambush marketing") was that the exercise of athlete publicity rights would diminish the value of exclusive IOC sponsorship arrangements. 
to $\$ 10,000$ annually in prize money before they enter college while retaining amateur status. ${ }^{40}$

Additionally, the NCAA now allows student-athletes to receive gifts for participating in bowl games or championships. For instance, athletic participation awards provide cash and merchandise (such as video games and jewelry, among other prizes) to players in football bowl games and the March Madness basketball tournament. A March 2012 article in Sports Business Journal provided some details:

For example, a senior on a team that runs the table and wins championships for the regular season, postseason conference tournament and NCAA tournament could secure gifts valued at up to $\$ 3,780$. Last year's comparable total was $\$ 3,380$. Up to 25 gift packages can be provided to a team by its school and by its conference for participating in this month's conference tournaments, according to NCAA bylaws. ${ }^{41}$

The total amount of the awards granted are now estimated at $\$ 5,600$ yearly per athlete. ${ }^{42}$ The NCAA also permits athletes' families to receive payments of up to $\$ 4,000$ to cover the cost of attending the men's and women's Final Four championship games as well as the College Football Playoffs. ${ }^{43}$

A modification that has particularly large implications for high-profile athletes, especially in basketball and football, is that cash from two funds

${ }^{40}$ Division I Manual, supra note $6, \boldsymbol{\Upsilon}$ 12.1.2.4.2 (stating that "[i] tennis, prior to full-time collegiate enrollment, an individual may accept up to $\$ 10,000$ per calendar year in prize money based on his or her place finish or performance in athletics events").

41 David Broughton, Higher Limits Bring Gift Package Upgrades, SporTs Bus. J. (Mar. 5, 2012), https://www.sportsbusinessdaily.com/Journal/Issues/2012/03/05/ Colleges/College-gifts.aspx [https://perma.cc/SZ6F-ZJ86]. In 2012, the NCAA allowed each bowl to award up to $\$ 550$ worth of gifts to 125 participants per school. In addition, participants were allowed to receive awards worth up to $\$ 400$ from the school and up to $\$ 400$ from the conference for postseason play, covering both conference title games and any bowl game. See David Broughton, Players Share the Wealth With Bowl Gifts, Sports Bus. J. (Dec. 3, 2012), https:// www.sportsbusinessdaily.com/Journal/Issues/2012/12/03/In-Depth/Bowl-gifts.aspx [https://perma.cc/QU5K-5QXZ].

${ }^{42}$ See Redacted Plaintiffs' Response Brief and Opening Brief on Cross-Appeal at 15, 17-18, In re NCAA Athletic Grant-In-Aid Cap Antitrust Litig., 2019 WL 5598019 (9th Cir. Oct. 23, 2019) (Nos. 19-15566, 19-15662) (“Jenkins' Appeal Brief").

${ }^{43}$ Michelle Brutlag Hosick, Council Adopts Final Four Family Travel Proposal, Nat'l Collegiate Athletic Ass'n (Jan. 23, 2019, 5:27 PM), http:/www.ncaa.org/ about/resources/media-center/news/council-adopts-final-four-family-travel-proposal [https://perma.cc/D2SH-GK4N]. 
created by the NCAA - the Student Assistance Fund ("SAF") ${ }^{44}$ and Academic Enhancement Fund ("AEF") ${ }^{45}$ — can be given to athletes. ${ }^{46}$ Though the NCAA created these resources to help student-athletes cover costs related to personal emergencies (e.g., bereavement-related travel), universities can now allocate these funds discretionarily for their student-athletes' benefit. One highly visible example is schools' provision of funds to athletes to pay premiums on loss-of-value insurance. Indeed, Zion Williamson would have been entitled to collect on an $\$ 8$ million loss-of-value insurance policy-that Duke University paid $\$ 50,000$ in premiums for-if he slipped past the number sixteen overall pick in the 2019 National Basketball Association ("NBA") draft. ${ }^{47}$

\section{The NCAA's Current Bylaws Regarding Amateurism}

Today, the NCAA views its amateurism principles as integral to its educationally-focused mission. In its bylaws, the NCAA states that it seeks to "provid[e] student-athletes with exemplary educational and intercollegiate-athletics experiences in an environment that recognizes and supports the primacy of the academic mission of its member institutions, while enhancing the ability of male and female student-athletes to earn a four-year degree." 48

The NCAA has several bylaws that address amateurism, including NIL payments. ${ }^{49}$ These bylaws restrict athletes in specific ways:

${ }^{44}$ See generally David McCoy, NCAA's Little-Known Student Assistance Fund, CBS MinN. (Jan. 12, 2014, 11:17 PM), https://minnesota.cbslocal.com/2014/01/12/ ncaas-little-known-student-assistance-fund/ [https://perma.cc/Z22T-XTUY].

${ }^{45}$ See Michelle Brutlag Hosick, DI To Distribute Revenue Based on Academics, Nat'l Collegiate Athletic Ass'N (Oct. 27, 2016, 12:36 PM), http:/www.ncaa.org/ about/resources/media-center/news/di-distribute-revenue-based-academics [https:// perma.cc/NMJ8-3DV5].

46 See Nat'l Collegiate Athletic Ass'n, 2019 Division I Revenue DistriBUTION PLAN (2019), https://ncaaorg.s3.amazonaws.com/ncaa/finance/d1/ 2019D1Fin_RevenueDistributionPlan.pdf [https://perma.cc/5GPY-L7UL].

${ }^{47}$ Mike Chiari, Report: Zion Williamson's \$8M Insurance Policy Revealed After Injury vs. UNC, BLEACHER REP. (Feb. 21, 2019), https://bleacherreport.com/articles/ 2821748-report-zion-williamsons-8m-insurance-policy-revealed-after-injury-vs-unc [https://perma.cc/CDU4-SYV2]; see also Jenkins' Appeal Brief, supra note 42, at 15.

${ }^{48}$ Division I Manual, supra note 6, 9 14.01.4 (emphasis added).

49 Prior to 2015-16, the NCAA required athletes to explicitly release claims for the NILs to their schools, conferences and the NCAA for live-in-game broadcasts. See Greg Lush, Reclaiming Student Atbletes' Rights to Their Names, Images and Likenesses, Post O'Bannon v. NCAA: Analyzing NCAA Forms for Unconscionability, 24 S. CAL. INTERDISC. L.J., 767, 767-69(2015). 
- Financial aid is "not considered to be pay or the promise of pay for athletics skill." 50

- Payments to athletes for athletic services are prohibited. ${ }^{51}$

- Athletes who accept payments may be subject to revocation of their amateur status and eligibility under severe conditions. ${ }^{52}$

- Athletes are prohibited from receiving money for promoting any "commercial product." 53

- Athletes who start a business may not use their "name, photograph, appearance or athletics reputation" to promote the business. ${ }^{54}$

Perhaps inconsistent with the NCAA's stated mission (along with modifications to the amateurism policy addressed in the previous sections) are two particular bylaws:

- The NCAA and its member institutions may use athletes to endorse their products and activities in a wide variety of circumstances. ${ }^{55}$

50 Division I Manual, supra note 6, 9 12.01.4.

${ }^{51}$ Id. ๆ 12.1.2.

${ }^{52}$ Id. I 12.1.2. This bylaw revokes amateur status and NCAA eligibility where a student-athlete: (1) "[u]ses his or her athletic skill (directly or indirectly) for pay in any form in that sport;" (2) "[a]ccepts a promise of pay even if such pay is to be received following completion of intercollegiate athletics participation;" (3) "[s]igns a contract or commitment of any kind to play professional athletics, regardless of its legal enforceability or any consideration received, except as permitted in Bylaw 12.2.5.1;" (4) "[r]eceives directly or indirectly, a salary, reimbursement of expenses, or any other form of financial assistance from a professional sports organization based on athletics skill or participation, except as permitted by NCAA rules and regulations;" (5)"[c]ompetes on any professional athletics team per Bylaw 12.02.11, even if no pay or remuneration for expenses was received, except as permitted in Bylaw 12.2.3.2.1;" (6) "[a]fter initial full-time collegiate enrollment, enters into a professional draft (see Bylaw 12.2.4);" or (7) "[e]nters into an agreement with an agent." Id.

53 Id. ๆ 12.5.2.1.

${ }^{54} \mathrm{Id}$. ๆ 12.4 .4 .

55 Id. I 12.5.1.1; see also Mike McIntire, The College Sports Tax Dodge, N.Y. Times (Dec. 28, 2017), https://www.nytimes.com/2017/12/28/sunday-review/collegesports-tax-dodge.html [https://perma.cc/F49X-RAXB]. Non-profit educational institutions have a special tax status such that athletic department revenues from commercial activities like sale of tickets and apparel are not subject to the Unrelated 
- While athletes may receive certain performance awards for athletics, they generally may not for academic achievement. ${ }^{56}$

\section{The Proper Role of Amateurism}

Given its history of extensive modifications of what acts do and do not run afoul of being an amateur athlete, it is reasonable to conclude that amateurism in college sports is whatever the NCAA dictates it to be at the time. With regularly shifting goal posts, it seems problematic to argue that this morphing concept of amateurism is necessary for college sports. We believe, however, that amateurism, properly understood, is an important feature of intercollegiate athletics.

The word amateurism derives from the Latin word "amator" which means lover. In common English, an amateur is someone who engages in activity for pleasure or love rather than for extrinsic reward or money. Ergo, Division I college basketball players remain amateurs so long as long as they do not receive pay for their participation. So, under this line of reasoning, a Division I college basketball player should be able to receive pay for endorsing a local car dealership because the underlying performance is for executing the endorsement, not for playing basketball. That is, NIL payments do not violate the core meaning of amateurism. Nevertheless, such payments are prohibited under the current NCAA rules.

In our view, as long as playing a college sport remains an extracurricular activity rather than a standalone commercial activity, amateurism should play a role. Many athletes in high profile college football and basketball programs already are cheated out of a proper learning experience. They may be admitted without adequate academic achievement or ability and hustled

Business Income Tax ("UBIT") because college athletics are an integral part of the education program of educational institutions (i.e. such revenues are substantially related to the educational program). See infra note 205 and accompanying text. If an educational institution pays athletes with its revenues instead of using them for educational purposes, it could lose its special tax status. In fact, in 2018, Congress tightened tax exempt status for college athletics by imposing an excise tax on salaries above $\$ 1$ million and eliminating a partial deduction for booster donations tied to the sale of game tickets. See Associated Press, College Coaches' Salaries Increase Despite Threat of New Tax, USA ToDAY (Dec. 13, 2017, 2:48 AM), https:// www.usatoday.com/story/sports/ncaaf/2017/12/13/college-coaches-salaries-increasedespite-threat-of-new-tax/108562894/ [https://perma.cc/W5RH-ZYKP].

56 See Brief of Amici Curiae, In re NCAA Athletic Grant-in-Aid Cap Antitrust Litig., 375 F. Supp. 3d 1058 (N.D. Cal. 2019) (No. 4:14-md-02541). But see DiviSION I MANUAL, supra note 6, ๆ 15.02.5.4 (listing "honorary award for outstanding academic achievement" as one exempted institutional financial aid). 
into phantom courses and majors. Most are required to spend well in excess of forty hours weekly preparing for and engaging in competition. ${ }^{57}$ If their amateur status is lifted and they begin to receive compensation, they will face more pressure to perform for their coaches, who, in turn, will be less restricted by the exigencies of the educational process. This will inevitably create a greater separation between student-athletes and the normal student body. Athletes would also have to pay taxes on their income, introducing a cadre of lawyers, financial advisors, agents, and tax accountants.

For those who believe that athletes must receive pay to avoid exploitation, the only complete solution is the professionalization of major college sports. But this would present problems for both the schools and athletes. Significantly, athletic programs in the NCAA's Division I Football Subdivision ("FBS") run a median deficit of $\$ 16.3$ million, ${ }^{58}$ according to the latest NCAA financial report. ${ }^{59}$ This deficit, moreover, does not include most capital expenditures and many indirect costs of athletic programs which would add millions of dollars to the financial drain. ${ }^{60}$ If college athletes received salaries, then this deficit, financed out of the school's educational budget,

57 Student-Athlete Time Demands, Penn Schoen Berland \& PAC 12 ConFERENCE (Apr. 2015), https://sports.cbsimg.net/images/Pac-12-Student-AthleteTime-Demands-Obtained-by-CBS-Sports.pdf [https://perma.cc/NSG3-GWKA].

58 Andrew Zimbalist, The NCAA Sports Model Is Broken, And It's Time For Congress To Step In, Forbes (Dec. 20, 2019, 8:00 AM), https:/www.forbes.com/sites/andrewzimbalist/2019/12/20/the-ncaa-sports-model-is-broken-and-its-time-for-congress-to-step-in/\#4118eea23d09 [https://perma.cc/YQ76-2H4M]. But see Andy Schwarz, The NCAA Isn't Going Broke, No Matter How Much You Hear It, FiveThirTyEight (Apr. 20, 2016, 1:44 PM), https:/fivethirtyeight.com/features/ the-ncaa-isnt-going-broke-no-matter-how-much-you-hear-it/ [https://perma.cc/ K3LL-6L9J].

59 NCAA Research, 14-Year Trends in Division I Athletics Finances 9 (2019).

${ }^{60}$ Note that the athletic department financial books count athletic scholarships at their quoted rate based on tuition, room and board, fees and required books rather than their actual expense to the school, based on marginal costs. In this sense, actual athletic costs are overstated. But the understatement from incomplete accounting of capital costs (facility construction and maintenance) and indirect costs (charging a share of the college administration's salaries, offices, travel, etc.) far outweighs any undercounting. Also note that the NCAA reporting system includes donations to athletics as revenue generated, but some of the athletic donations may displace donations to a school's general fund. While it is true that big-time college athletics revenues have been growing rapidly in recent decades, expenses have grown more rapidly. The basic problem is that college athletics departments do not have stockholders who seek reports of quarterly profits to bolster stock prices and dividends, instead they have stakeholders who seek victories. Athletic directors respond accordingly, resulting in little cost discipline. 
would balloon. Eventually, the extent of the increase in the deficit will diminish as coaches and athletic administrators, who are now paid out of the value of the athletes they recruit, would see their salaries decrease. Further compounding these problematic implications is that as the athletic department deficit grows, there is less funding available for women's sports, which makes Title IX compliance increasingly more difficult. ${ }^{61}$

The argument in favor of paying athletes often references the multimillion-dollar salaries received by coaches and top administrators, as well as current expenditures on ultra-lavish facilities. ${ }^{62}$ Not to pay athletes in the face of these bloated salaries is seen as unjust and unseemly. With this, we agree. Indeed, in 2019, there were 176 college football and men's basketball coaches who received salaries exceeding $\$ 1$ million, 71 whose salaries exceeded $\$ 3$ million, and 38 whose salaries exceeded $\$ 4$ million. ${ }^{63}$ The highest paid coach was Dabo Swinney at Clemson University, with a guaranteed salary of $\$ 9.3$ million plus bonuses of $\$ 1.1$ million and a potential buyout clause worth $\$ 50$ million. ${ }^{64}$ Swinney's assistant coaches collectively earned $\$ 6.8$ million, raising the total compensation for all football coaches at Clemson to $\$ 17.2$ million, not including their handsome perquisites and opportunities for outside income. Perquisites generally include free use of cars, housing subsidies, country-club memberships, private jet services, exceptionally generous severance packages, and more. ${ }^{65}$ Coaches also have alluring

6120 U.S.C. $\$ \S 1681-1688$ (2018). In O’Bannon v. National Collegiate Atbletic Ass'n, 7 F. Supp. 3d 955 (N.D. Cal. 2014), affd in part, vacated in part, 802 F.3d 1049 (9th Cir. 2015), Judge Wilken rejected the NCAA's procompetitive justification that its amateurism limits enable increased support for women's sports stating that the NCAA could mandate that schools direct a greater portion of their licensing revenue generated by football and basketball to the other sports. $I d$. at 1000-01.

${ }^{62}$ For example, in 2017 Clemson University opened its ultra-extravagant \$55 million, 142,000 square-foot Reeves Football Complex that includes a miniature golf course, bowling lanes, a barber shop, nap room and wiffle ball court. Following Clemson's lead, the University of South Carolina's new $\$ 50$ million football operations center opened in January 2019 equipped with a recording studio and barber shop. Manie Robinson, Staying Power: Clemson Football Has Changed the Game In Facilities, Greenville News (July 30, 2019, 8:00 AM), https:// www.greenvilleonline.com/story/sports/college/clemson/2019/07/30/staying-powerclemson-football-facility-college-athletics-facilities/1839960001/ [https://perma.cc/ AM6E-Z6UY].

632019 NCAAF Coaches Salaries, USA TODAY, https://sports.usatoday.com/ncaa/ salaries/ [https://perma.cc/MG9M-4EEC].

${ }^{64} \mathrm{Id}$.

${ }^{65}$ One eye-popping severance clause appeared in the contract of Mike Sherman, Texas A\&M's football coach, who, if terminated, would have been paid $\$ 150,000$ a month for the remainder of his contract that would have amounted to a " $\$ 7.8$ 
opportunities to earn outside income via apparel or sneaker endorsements, the lecture circuit, summer camps, and book contracts. ${ }^{66}$ In forty states, the head football or basketball coach on a college team within the state makes more in guaranteed compensation than the state's governor. ${ }^{67}$

Defenders of multimillion-dollar coaches' salaries argue that coaches' compensation packages are driven by market forces. While this may be true, the market for coaches is buoyed by artificial factors: (1) the lack of compensation paid to the athletes; (2) substantial tax privileges given to intercollegiate sports; (3) a lack of shareholder demand for dividend distributions or higher profits to bolster stock prices at the end of every quarter; (4) the university and statewide financial support given to athletic departments; and (5) the incentives of athletic directors who negotiate coaches' salaries and whose own worth rises with the salaries of their employees.

The answer to the bloated spending though, in our view, is not to pay the athletes a salary; it is to cap coaches' and administrators' salaries, limit the expenditures on lavish facilities used for a single sport, and reinforce the educational mission of the school. ${ }^{68}$ We believe that these restrictions would require an antitrust exemption. ${ }^{69}$ Such an exemption should be conditioned on the NCAA ensuring that athletes receive a robust educational and social experience in college, safeguarding athletes' health, and providing health and lost-income-from-injury insurance. Significantly, this plan would permit athletes to receive payments for product endorsements from third parties or other use of athlete NIL rights with appropriate restrictions. Our

million golden handshake." ANDrew Zimbalist, Circling the BAsEs: Essays on the Challenges and Prospects of the Sports Industry 177 (2011).

${ }^{66}$ To be clear, outside of basketball and football, coaches do not receive such lavish remuneration. In Divisions II and III no coaches benefit from this largesse.

${ }^{67}$ Reuben Fischer-Baum, Infographic: Is Your State's Highest-Paid Employee a Coach? (Probably), DeAdspin (May 9, 2013, 3:23 PM), http://deadspin.com/infographic-is-your-states-highest-paid-employee-a-co-489635228 [https://perma.cc/ 4Z3N-PL9R].

${ }^{68}$ See Jayma Meyer \& Andrew Zimbalist, Reforming College Sports: The Case for a Limited and Conditional Antitrust Exemption, 62 The Antitrust Bulletin (2017). Also, note that such a cap on coaches' salaries would have no discernible impact on the quality of college coaches. The best alternative employment for these coaches would be coaching at lower levels at much lower salaries. If a few went to the professional leagues, the existing professional coaches would become available to coach at the college level.

69 The NCAA has already lost an antitrust case when it tried to impose compensation limits on assistant basketball in the 1990s. See Law v. Nat'l Collegiate Athletic Ass'n, 134 F.3d 1010 (10th Cir. 1998). Price fixing is a restraint of trade and generally seen as a per se violation of antitrust laws. See discussion infra Part II.A. 
proposed plan for NIL payments, along with an antitrust exemption, is explained in Part V. ${ }^{70}$

Another factor in athlete pay is whether the college-sports brand would suffer if pay for play, including the institution paying for athletes' NILs, were introduced. ${ }^{71}$ Some claim that college sports derive much popularity from the presumption that the athletes are students, not "ringers" or professionals who do not attend class. If the athletes are matriculated students who attend and participate in classes alongside non-student-athletes, a link is formed between the athletes and non-athletes. The team is thus perceived to be the school team, which stimulates support from current students, administrators, alumni, and local businesspeople. If the link between athlete and student is disrupted, however, then the special fan attachment to the team could dissipate, morphing college sports into little more than a minor league professional basketball or football league, with attendant reductions in attendance and television contracts. Proponents of pay for play or for NILs retort that this position ignores the experience of the Olympics, where athletes have not been required to be amateurs since the 1980s, yet the popularity of the Olympic Games has continued to grow in recent decades. ${ }^{72}$ Each side of this debate has proffered non-dispositive evidence, and it is thus fair to say that this debate has not yet been resolved. ${ }^{73}$

Certain opponents of pay for play argue that NIL payments by third parties will diminish the progress that women have made toward gender

70 See infra Part V.

71 This issue is further discussed from a legal standpoint in Part II supra.

72 In 1984, the International Olympic Committee ("IOC") voted to allow the International Federation of each sport to set the eligibility rules for their sport, within some limits. In 1987, the IOC voted to permit professional tennis players to participate in the Games and in 1989, the IOC extended the welcome to all professional athletes. See Andrew Zimbalist, Circus Maximus: The Economic GamBLE BeHind Hosting THE OLYMPICS AND THE WORLd Cup ch. 2 (2015). It should be noted, however, that the compensation of Olympic athletes in the United States is determined by each sport's federation and tends to be nominal. Thus, almost all of the Olympic athletes receive below a livable wage, and while they are "paid," the perception of the public may still be the athletes are not professionals. Top Olympic athletes from other countries, especially Asian countries, receive more robust compensation, and those who win medals usually receive hundreds of thousands of dollars in rewards. In those countries, government funding supports the Olympic program.

73 Experts, equipped with survey evidence, in the antitrust cases present much conflicting evidence on this hypothetical question. See Cody J. McDavis, Paying Students to Play Would Ruin College Sports, N.Y. Times (Feb. 25, 2019), https:// www.nytimes.com/2019/02/25/opinion/pay-college-athletes.html [https://perma.cc/ PLQ3-Z9ZT]. 
equality in collegiate sports since Title $\mathrm{IX}^{74}$ was enacted in $1972 .{ }^{75}$ The concern is that high-profile men playing football and basketball will receive the vast majority of NIL payments and Title IX will not apply to require equity because the discrimination would not be engaged in by the organization receiving federal funds (i.e., educational institutions). Of course, if the institution directly pays athletes for use of their NILs, which is not what this Article proposes, then there is little question that Title IX would apply, mandating equivalent NIL payments to women either as part of its financial-aid or benefits-and-opportunities requirements. ${ }^{76}$ Yet Title IX's requirements may apply even if schools do not pay the NIL payments to athletes but are involved in one form or another, directly or indirectly, with respect to the third party payments-e.g., in an administrative or compliance capacity. ${ }^{77}$ To the extent that NILs become a recruiting tool, then

74 Title IX requires that women and men be provided equitable opportunities to participate in sport, to receive financial aid proportional to their participation numbers and equivalent treatment with respect to over-all benefits. Equivalent benefits and treatment that must be provided specifically include publicity and promotions, support services and recruitment of athletes. For a fuller explanation, see generally WOMEN's SPORTS FOUNDATION, https://www.womenssportsfoundation.org/ [https:// perma.cc/L3ZZ-SCN2].

75 This is in addition to the arguments made above regarding the possibility that group licenses paid by educational institutions to athletes, especially in football and basketball, or third-party payments now made to individuals, will diminish athletic department revenues and therefore harm women's sports. See supra Part I.D.

76 The schools then might need to either match the amount paid by third parties to men or require that the respective third party equally make payments for women athletes or teams. This would not be dissimilar to Title IX's requirements regarding fundraising. See Donna Lopiano, Gerald Gurney, Fritz Polite, David B. Ridpath, Allen Sack, Sandy Thatcher \& Andrew Zimbalist, A Critical Analysis of Proposed Models of College Atblete Compensation, Drake Group (Mar. 2, 2019), https:// www.thedrakegroup.org/wp-content/uploads/2019/10/COMPENSATION-POSITION-PAPER-March-2.pdf [https://perma.cc/K52T-NGJF].

77 In a situation involving very different facts, the Office of Civil Rights in 2017 pointed out that if a member institution assists an outside organization in making employment available to any of its students, it must make certain that the employment is available without discrimination on the basis of sex. Id.; see also Michael McCann, Key Questions, Takeaways From the NCAA's NIL Announcement, SporTs ILLUSTRATED (Oct. 29, 2019), https://www.si.com/college/2019/10/30/ncaa-nameimage-likeness-announcement-takeaways-questions [https://perma.cc/9FDHYF3W]; Mark Emmert, If College Atbletes Could Profit Off Their Marketability, How Much Would They Be Worth? In Some Cases, Millions, USA Today (Oct. 9, 2019, 3:13 PM), https://www.usatoday.com/story/sports/college/2019/10/09/college-athleteswith-name-image-likeness-control-could-make-millions/3909807002/ [https:// perma.cc/D9ME-MVBL]; Jenny Dial Creech, More Progress Must Be Made To Secure Equal Pay For Women's Sports, Hous. Chron. (June 10, 2018, 8:44 PM), https:// 
"there is a question as to whether that school's knowledge creates an obligation [under Title IX] to try to ensure similar opportunities are offered for the other gender." 78 Further, since promotional efforts must be equitable under Title IX for men and women, if schools promote NIL opportunities from third parties for men or men's teams, then they must devote qualitatively similar efforts to women or women's teams. ${ }^{79}$

NIL payments made by third parties, even if generally not as large to female athletes as to males, may meaningfully benefit high-profile female athletes. ${ }^{80}$ This is significant given that women today have fewer opportunities to become professional athletes. Just consider how many men play football professionally. Indeed, the sponsor of the California bill, Nancy Skinner, made this point stating that "women [athletes] really should have a shot at getting something while they're in college" because of the lack of professional opportunities for women after college. ${ }^{81}$ As explained by Congresswoman Skinner, many female athletes, whether nationally or locally known, have their moment in the spotlight, with corresponding earning power, while in college. For them, the chance to receive NIL payments while in college is a significant benefit. For example, Katelyn Ohashi, a star gymnast at the University of California, Los Angeles, whose perfect (10.0) floor rou-

www.houstonchronicle.com/sports/columnists/dialcreech/article/More-progressmust-be-made-to-secure-equal-pay-12982980.php [https://perma.cc/BU5Z-N9EE].

${ }^{78}$ Paul Steinbach, What Title IX Fallout Might NIL Legislation Pose?, ATHLETIC Bus. (Jan. 2020), https://www.athleticbusiness.com/college/how-might-nil-legislation-be-impacted-by-title-ix.html [https://perma.cc/AW5X-SF9L].

${ }^{79} I d$.

80 See supra note 74; see also Dan Murphy, What California Bill Means For NCAA Image and Likeness Debate, ESPN (Oct. 1, 2019), https://www.espn.com/college-football/story/_/id/27585301/what-california-bill-means-ncaa-image-likeness-debate [https://perma.cc/4VZY-XQ9X] ("Sen. Skinner, co-author Sen. Steven Bradford, and Gov. Newsom all said they felt the law actually opens more doors for female atbletes who can now promote themselves rather than relying on the schools, which typically spend most of their marketing budget on revenue sports like football and men's basketball."); Cecelia Townes, Why California's Fair Pay To Play Act Could Be A Financial Win For Female Athletes, Forbes (Sept. 16, 2019, 2:08 PM), https:// www.forbes.com/sites/ceceliatownes/2019/09/16/why-the-california-fair-pay-toplay-act-could-be-a-financial-win-for-female-athletes/\#388a592d4c72 [https:// perma.cc/6PHN-YCUV] ("Endorsements (and other opportunities to earn income from one's NIL) may be the only opportunity that a talented female athlete has to be compensated for her skills.")

81 See Emmert, supra note 77; Elliot Almond, What Does the NCAA Board's Vote On Paying Athletes Actually Mean?, Mercury News (Oct. 29, 2019, 4:33 PM), https://www.mercurynews.com/2019/10/29/what-does-the-ncaa-boards-vote-onpaying-athletes-actually-mean/ [https://perma.cc/P7L2-TFPX]. 
tine in 2019 went viral when posted on YouTube, ${ }^{82}$ pointed out that her situation would have been dramatically different if she could have profited from that video. ${ }^{83}$ Ohashi said she felt stifled by NCAA regulations as she gained name recognition: ${ }^{84}$

Along with this came a lot of attention and opportunities, but I couldn't capitalize on them. I was handcuffed by the NCAA rules that prevented me from deriving any benefit from my own name and likeness, regardless of the fact that after my final meet, I had no pro league to join. ${ }^{85}$

Finally, some commentators argue that payment for play will reduce the ugly underbelly of surreptitious payments to athletes. ${ }^{86}$ Indeed, former U.S. Secretary of State Condoleezza Rice, as Chairperson for the Committee that evaluated the recent NCAA basketball scandal, ${ }^{87}$ explained that athletes

${ }^{82}$ UCLA Athletics, Katelyn Ohashi - 10.0 Floor (1-12-19), YouTube (Jan. 12, 2019), https://www.youtube.com/watch?v=4ic7RNS4Dfo [https://perma.cc/ M5QX-Z6XC].

${ }_{83}$ Michelle R. Martinelli, Viral Former UCLA Gymnast Katelyn Ohashi Slams NCAA, Felt 'Handcuffed' by Profit Rules, USA TODAY (Oct. 9, 2019, 9:25 AM), https://ftw.usatoday.com/2019/10/katelyn-ohashi-ucla-viral-gymnast-slams-ncaafair-pay-to-play [https://perma.cc/7PY4-NC3C].

${ }^{84} \mathrm{Id}$.

85 One cannot help but ask whether it would have been different for Olympic Swimmer Missy Franklin if she had not faced the choice of making money from her NIL only by dropping out of University of California-Berkeley. She dropped out after two years in order to sign with an agent and pursue attractive endorsement deals in 2015. She never regained the same level of swimming success. Or, would it have been different for Katie Ledecky, another Olympian swimmer, who in 2018 stopped competing for Stanford where she earned numerous NCAA titles and records in order to accept professional endorsements and sponsorship opportunities? See Dial Creech, supra note 77.

${ }^{86}$ See generally Ryan Swanson, Want To Clean Up College Atbletics? Pay The Players., Wash. PosT (Oct. 2, 2017, 6:00 AM), https://www.washingtonpost.com/news/ made-by-history/wp/2017/10/02/want-to-clean-up-college-athletics-pay-the-players/ [https://perma.cc/P3UL-BKVQ].

87 On September 26, 2017, the Federal Bureau of Investigation announced ten arrests involving various big-name Division I basketball programs and Adidas executives on various corruption and fraud charges including bribery, money laundering, and wire fraud. See Lauren Thomas, FBI arrests NCAA basketball coaches and Adidas rep in bribery probe involving recruitment, CNBC (Sept. 26, 2017, 4:19 PM), https://www.cnbc.com/2017/09/26/ncaa-basketball-officials-arrested-on-fraud-andcorruption-charges.html [https://perma.cc/7VUV-TLBR]. The core allegations were that student-athletes were being paid to attend certain schools and participate in their basketball programs. See id. 
should be entitled to NIL payments for this very reason. ${ }^{88}$ She then said that the NCAA's rules relating to NIL payments are "incomprehensible," and noted that, when she sees policies as "confused" as the NCAA's is with respect to NILs, she thinks " "why haven't you gone and looked at this before?' It's really time to come to terms with name, image and likeness." 89

\section{The Legal Landscape of Amateurism and Paying College Athletes, INCLUding FOR THEIR NILs, IN COLlEge SPORTS ${ }^{90}$}

Litigation aimed at providing college athletes with pay or additional benefits and rights has relied on various causes of action pursuant to federal, state, and common laws.

Antitrust laws have been the most widely used to challenge the NCAA's amateurism rules. In these cases, the NCAA has argued that, even if its rules are anti-competitive, they are necessary to preserve amateurism in order to protect the uniqueness of college sports and thus demand for the brand. ${ }^{91}$ Right-of-publicity-claims have proved to be more complicated because they turn on state laws and common law, and the First Amendment and copyright laws may offer strong defenses, depending on the usage (for example, live broadcasts versus video games).

Athletes have also resorted to employment and labor laws in order to find a friendly basis for pursuing their claims to receive payment, including the Fair Labor Standards Act, arguing that they are employees, and the National Labor Relations Act, arguing that they be allowed to unionize. As

${ }^{88}$ Christine Brennan, NCAA Rules Are 'Incomprehensible, Says Condoleezza Rice, USA TODAY (May 9, 2018, 7:24 PM), https://www.usatoday.com/story/sports/ncaab/ 2018/05/09/ncaa-mens-basketball-rules-incomprehensible-condoleezza-rice/

596549002/ [https://perma.cc/7B5E-CGNT]. The NCAA granted a waiver to Notre Dame basketball star, Arike Ogunbowale to earn money from Dancing with the Stars soon after Notre Dame won the Final Four tournament when Ogunbowale hit a winning three point shot that went viral. The NCAA reasoned that the show was unrelated to her basketball abilities. Dr. Rice used this as an example of the incomprehensibleness of the rules. See id.

89 Id.

90 See Meyer \& Zimbalist, supra note 68 (including certain of the same analysis as in this Section but with more detail).

91 The rules that have been challenged under the antitrust laws include not only payment and benefits to athletes for their play, but also the length and number of scholarships available to athletes, the length of competitive seasons, the selection of teams to participate in national championships, the transfer of athletes between schools and the payment of assistant coaches. Meyer \& Zimbalist, supra note 68, at nn. 51-54. 
explained, infra, these employment- and labor-law-based efforts have not succeeded to date. ${ }^{92}$

\section{A. Atbletes Have Received Additional Benefits Under the Antitrust Lawsuits}

Antitrust laws, and their judicially created frameworks, while not easy to apply to intercollegiate sports, have been the most fertile ground for chipping away at the NCAA's amateurism rules.

The Sherman Act, ${ }^{93}$ designed to govern commercial activities, ${ }^{94}$ prohibits contracts, combinations, or conspiracies that unreasonably restrain trade. ${ }^{95}$ Once a court finds a rule fundamentally commercial under the Sherman Act, a court then must address whether the rule unreasonably restrains trade. ${ }^{96}$ With respect to the NCAA, because the product-competitive sports-requires joint activity among individual institutions (i.e., a team cannot play against itself), courts apply a rule of reason analysis to determine whether the rule is unreasonably anticompetitive. The judicially created rule of reason framework involves three burden-shifting steps. First, the plaintiff has the burden of proving that the restraint creates anti-competitive effects. If the plaintiff successfully argues this point, the analysis moves to the second step, in which the burden shifts to the defendant to prove pro-competi-

92 See, e.g., Ben Strauss, N.L.R.B. Rejects Northwestern Football Players' Union Bid, N.Y. Times (Aug. 17, 2005), https://www.nytimes.com/2015/08/18/sports/ncaafootball/nlrb-says-northwestern-football-players-cannot-unionize.html [https:// perma.cc/5UDB-GBZV].

93 Codified in 15 U.S.C. $\$ \S 1-38$ (2018), the Sherman Antitrust Act is a federal antitrust statute which prohibits acts that restrict interstate commerce and competition. Section 1 of the Act states that "[e]very contract, combination in the form of trust or otherwise, or conspiracy, in restraint of trade or commerce among the several States, or with foreign nations, is declared to be illegal." Id. $\S 1$.

94 While nonprofit organizations, like many universities and colleges, are not categorically exempt from the Sherman Act, "when they perform acts that are the antithesis of commercial activity, they are immune from antitrust regulations." United States v. Brown Univ. in Providence in St. of R.I., 5 F.3d 658, 665 (3d Cir. 1993).

95 See generally Meyer \& Zimbalist, supra note 68, at 41; see also Agnew v. Nat'l Collegiate Athletic Ass'n, 683 F.3d 328, 340 (7th Cir. 2012) (opining that "no knowledgeable observer could earnestly assert that big-time college football programs ... do not anticipate economic gain from a successful recruiting program. Despite the nonprofit status of NCAA member schools, the transactions those schools make with premier athletes-full scholarships in exchange for athletic services-are not noncommercial, since schools can make millions of dollars as a result of these transactions").

96 See generally O’Bannon v. Nat'l Collegiate Athletic Ass'n, 802 F.3d 1049 (9th Cir. 2015). 
tive benefits flowing from the restraint. If the defendant's justifications are "sufficient," the burden shifts back to the plaintiff, in the third step, to show that the challenged conduct is not reasonably necessary to achieve the legitimate benefits or that comparable procompetitive benefits could be achieved through a less restrictive alternative ("LRA") that is virtually as effective and as economically efficient. Courts, at least implicitly, try to assess the legitimacy of, or weigh, these pro- and anti-competitive effects and the LRA, and therefore determine whether the virtues of the anti-competitive conduct justify the adverse impact. Their judgment turns on whether the dominant or net effect of the restraint, or of the LRA, is to promote competition or hinder it. ${ }^{97}$

\section{The Supreme Court's Decision in Board of Regents}

The Supreme Court has issued just one antitrust decision relating to college sports: National Collegiate Atbletic Ass'n v. Board of Regents of University of Oklaboma ("Board of Regents"). ${ }^{98}$ It discusses amateurism only in dicta. The case involved the NCAA's control (limitation) of how many games a college could broadcast on national TV and the prices for such broadcasts. The Court quickly concluded that the challenged contracts that schools jointly negotiated with television networks were commercial rules and, accordingly, that the Sherman Act applied. ${ }^{99}$

Next, the Court applied the rule of reason and its three-step burdenshifting analysis. ${ }^{100}$ First, the Court found that the restraint both limited output (reduced the number of games televised) and restricted prices (set a minimum aggregate price)_ which are "paradigmatic examples of restraints of trade that the Sherman Act was intended to prohibit." ${ }^{101}$ Shifting to the second step of the rule of reason analysis, the Court stated that the contracts, as "hallmarks of anticompetitive behavior," placed a "heavy burden" on the NCAA to establish an affirmative defense that justifies the deviation from a free market. ${ }^{102}$ The Court then upheld the lower court's

97 See Meyer \& Zimbalist supra note 68, at 36-39.

98 Nat'l Collegiate Athletic Ass'n v. Bd. of Regents of Univ. of Okla., 468 U.S. 85 (1984).

99 "The specific restraints on football telecasts that are challenged in this case do not, however, fit into the same mold as do rules defining the conditions of the contest, the eligibility of participants, or the manner in which members of a joint enterprise shall share the responsibilities and the benefits of the total venture." $I d$. at 117 (emphasis added); see infra notes 106-27 and accompanying text.

100 See Bd. of Regents, 468 U.S. at 101.

101 Id. at $107-08$.

$102 \mathrm{Id}$. at 113. 
findings that the pro-competitive justifications of protecting a live audience, establishing an efficient marketing strategy, and preserving competitive balance were not supported by the evidence, and thus did not "offset" the anticompetitive limitations on price and output. ${ }^{103}$

While the Court's holding was straightforward, its opinion included discourse that the NCAA has since relied on regularly to justify its refusal to pay athletes, including refusal to permit NIL payments to athletes:

One clear effect of most, if not all, of these regulations [including those relating to eligibility] is to prevent institutions with competitively and economically successful programs from taking advantage of their success by expanding their programs, improving the quality of the product they offer, and increasing their sports revenues. Yet each of these regulations represents a desirable and legitimate attempt "to keep university athletics from becoming professionalized to the extent that profit making objectives would overshadow educational objectives."104

In further dicta, the Court said that college athletes "must not be paid, must be required to attend class, and the like." 105 The Court did not analyze whether pay-for-play rules would be unreasonably anti-competitive and violations under the Sherman Act because payments to athletes were irrelevant to the issue at hand: the legality of the rules on TV contracts.

\section{The Ninth Circuit's Decision in O'Bannon}

Whether the NCAA rules regarding payments to athletes violated the Sherman Act was at the core of the Ninth Circuit's decision in O'Bannon $v$. National Collegiate Atbletic Ass'n. ${ }^{106}$ Edward O'Bannon was a basketball player on the University of California, Los Angeles national championship team in 1995. After discovering that his likeness was used in a commercial video game without his permission and without the promise of any compensation for use of his property rights, he brought an antitrust suit against the

103 Because step two was not satisfied, the Court never reached consideration of a less restrictive alternative, although it stated that it agreed with the lower court's conclusion that if the procompetitive justifications had been supported by the evidence, they could be achieved by a less restrictive alternative. Id. at 102 .

104 Id. at 123.

$105 I d$. (emphasis added).

106 See O'Bannon v. Nat'l Collegiate Athletic Ass'n, 7 F. Supp. 3d 955 (N.D. Cal. 2014), affd in part, vacated in part, 802 F.3d 1049 (9th Cir. 2015), cert denied, 137 S. Ct. 277 (2016); In re NCAA Student-Athlete Name \& Likeness Litig., 4:09-cv-1967 CW, 4:09-cv-3329 CW, 2015 WL 5005901 (N.D. Cal. Aug. 19, 2015) (which is the consolidation with Keller v. Elec. Arts, Inc., 4:09-cv-1967CW, 2015 WL 5005057 (N.D. Cal. Aug. 18, 2015)). 
NCAA $^{107}$ on behalf of purported classes of FBS football and Division I men's basketball players. The case sought to enjoin NCAA rules that prohibited payments to athletes for their NILs in three submarkets: (1) live game telecasts; (2) sports video games; and (3) game rebroadcasts, advertisements, and other archival footage. ${ }^{108}$

The issue in the case, brought under the Sherman Act, was whether the agreement to prevent such payments to athletes for their NILs was an unreasonable restraint of trade. ${ }^{109}$ Embedded in the case is whether athletes have rights of publicity for usage in the three submarkets. If they do not, then they would lack standing and suffer no antitrust injury as a result of the agreement. ${ }^{110}$ On summary judgment motion, the Northern District of California court found that the athletes had standing and satisfied the antitrust injury without specifying in which submarket the harm occurred. ${ }^{111}$

After much legal maneuvering, ${ }^{112}$ the parties proceeded to a bench trial on the merits of the antitrust claim. Judge Claudia Wilken issued a 99-page opinion in 2014, finding the NCAA rules to be commercial and then applying the three-part rule of reason analysis to determine whether the alleged prohibitions violated the Sherman Act. First, she found that the prohibitions constituted an anticompetitive restraint - a price-fixing agreement. The

107 At the same time, Michael Keller, Ed O'Bannon and others brought a separate lawsuit against Electronic Arts ("EA") alleging an infringement of their rights of publicity in EA produced video games under California's anti-SLAPP law. Keller v. Elec. Arts, Inc., 724 F.3d 1268, 1276 (9th Cir. 2013).

108 O'Bannon, 7 F. Supp. 3d. at 963.

109 Id.

110 Also, the court analyzed the three proposed submarkets to determine if there was injury to competition since groups of athletes would not compete with each other to sell their rights. The court concluded that groups of athletes would have an incentive to cooperate to sell packages of rights to the buyers. Id. at 994.

111 In re NCAA Student-Athlete Name \& Likeness Licensing Litig., 37 F. Supp. 3d 1126, 1155 (N.D. Cal. 2014). The NCAA unsuccessfully sought an interlocutory appeal on this matter. In re NCAA Student-Athlete Name \& Likeness Licensing Litig., No. C 09-1967 CW, 2014 WL 1949804 (N.D. Cal. May 23, 2014) (leave to file for reconsideration denied); In re NCAA Student-Athlete Name \& Likeness Licensing Litig., No. C 09-1967 CW, 2014 WL 12642228 (N.D. Cal. May 23, 2014) (motion to certify appeal denied). It argued that neither the Supreme Court nor any circuit court had squarely addressed whether athletes have a right of publicity for the use of the NILs in sports broadcasts. Defendant NCAA's Notice of Motion and Motion to Certify Pursuant to 28 U.S.C. $§ 1292$ (b) Court's Order Resolving Cross Motions for Summary Judgment at 4, In re NCAA Student-Athlete Name \& Likeness Licensing Litig., 37 F. Supp. 3d 1126 (N.D. Cal. 2014) (No. 1032).

112 The procedural posture of this case is long and complicated, including motions to dismiss and for summary judgment and interlocutory appeals. 
schools had agreed to rules prohibiting NIL payments to athletes for group licenses. ${ }^{113}$ Next, under the second step, ${ }^{114}$ Judge Wilken accepted as valid two of the NCAA's justifications, finding that amateurism played a "limited" role in maximizing consumer demand ${ }^{115}$ and that integrating athletics and academics was a "narrow" pro-competitive goal of increasing the quality of athletes' education. ${ }^{116}$

Moving to the third step under the rule of reason analysis, Judge Wilken found two less restrictive alternatives were available to fulfill the NCAA's stated pro-competitive justifications of amateurism and integration:

- Payment of scholarships up to cost of attendance ("COA") (an increase of between $\$ 2,000$ and $\$ 6,000$ per year depending on the school over the previous grant-in-aid ("GIA") amount). ${ }^{117}$

- Payment of up to $\$ 5,000$ a year to be held in trust for when the athlete leaves or graduates from college with the requirements that all athletes on a team receive the same amount and that the funds be generated from group licenses.

Both sides then had reason to be dissatisfied and appealed to the Ninth Circuit. On appeal, the Ninth Circuit agreed that the restriction of no payments for group licensing of NILs was a commercial restraint subject to the Sherman Act.

In applying the three-step burden-shifting framework, the Ninth Circuit first said that the restraint had a "significant" anti-competitive effect by eliminating price competition among schools. ${ }^{118}$ Moving to the second step in the rule of reason analysis, it accepted that amateurism and integration were pro-competitive justifications because they preserve the popularity

113 O'Bannon, 7 F. Supp. 3d. at 973. But see Keller v. Elec. Arts, Inc., 724 F.3d 1268, 1284 (9th Cir. 2013) (focusing only on the video-game market).

114 O'Bannon, 7 F. Supp. 3d. at 973.

115 Id. at 1001.

${ }^{116} \mathrm{Id}$. at 1003 .

117 GIA includes room, board, tuition, fees and required books for courses. COA adds miscellaneous expenses such as travel to and from campus, other books and supplies, laundry expenses, etc. Schools determine their respective COA based on a federally mandated formula. Given the discretion available in applying the formula, some schools are calculating the applicable amount on the high side and allegedly are gaining recruiting advantages. The COA, however, is limited by what is offered to other non-athlete scholarship students. Id. at 965, 974.

118 O'Bannon v. Nat'l Collegiate Athletic Ass'n, 802 F.3d 1049, 1070-72 (9th Cir. 2015). 
of intercollegiate sports and broadened choices, respectively. Third, the Ninth Circuit considered the proposed LRAs. Ultimately, the court upheld Judge Wilken's holding that the NCAA could restrict the schools' ability to award scholarship amounts above the COA, agreeing that this was "substantially" less restrictive than a rule prohibiting payments beyond GIA and would not "significantly" increase costs. ${ }^{119}$ The panel's reasoning focused on the need for amateurism in college sports: (1) amateurism requires no payment to athletes, so there would be no amateurism if there were payments and (2) payments up to the COA were "tethered" to academics, and therefore preserved the concept of amateurism. Writing for the panel, Judge Bybee explained:

The difference between offering student-athletes education-related compensation and offering them cash sums untethered to educational expenses is not minor; it is a quantum leap. Once that line is crossed, we see no basis for returning to a rule of amateurism and no defined stopping point .... At that point the NCAA will have surrendered its amateurism principles and transitioned from its 'particular brand of football' to minor league status. ${ }^{120}$

That said, the panel split on trust fund stipends for NIL rights, with the majority finding that they violated principles of amateurism because they were untethered to academics. Chief Judge Thomas's dissent on this issue challenged the artificiality of the majority's distinction and detailed the evidence that showed that small amounts of cash payments (beyond COA) provided to athletes after they left school would not harm the principle of amateurism. Plus, Chief Judge Thomas pointed out, amateurism, a "nebulous" concept, is relevant as a pro-competitive justification in an antitrust analysis only to the extent that it relates to consumer interest, which is a quantitative effect. ${ }^{121} \mathrm{He}$ stated there was no showing that such small, deferred payments would harm consumer interest. Finally, Chief Judge Thomas stressed the difficulty in resolving whether athletes should be paid for play: "The national debate about amateurism in college sports is important. But our task as appellate judges is not to resolve it. Nor could we." ${ }^{122}$

\footnotetext{
119 Id. at $1074-75$.

${ }^{120}$ Id. at 1078-79 (quoting Nat'l Collegiate Athletic Ass'n v. Bd. of Regents of Univ. of Okla., 468 U.S. 85, 101-02 (1984)).

${ }^{121} I d$. at 1083 (Thomas, C.J., concurring in part and dissenting in part).

122 Id. The O'Bannon Plaintiffs compared the NCAA's reliance on amateurism to the defendant's defense in United States v. Trans-Missouri Freight Ass'n, 166 U.S. 290 (1897), wherein the Court said that the antitrust laws do not permit the defendant to establish a legally cognizable interest in the suppression of competition: "These considerations are, however, not for us. If the act ought to read as contended for by
} 
Again, both sides had reason to be dissatisfied. Accordingly, after the plaintiffs' request for an en banc rehearing to the full Ninth Circuit Court of Appeals was denied, ${ }^{123}$ in a somewhat unusual consensus on the need for review, both the plaintiffs and the NCAA submitted petitions for a writ of certiorari to the Supreme Court. ${ }^{124}$ But both petitions were ultimately denied. ${ }^{125}$ As a result, the NCAA's regulations were left vulnerable to more challenges. $^{126}$

\section{Jenkins and Alston: NCAA "Grant-in-Aid" Litigation}

Two recent antitrust class action cases have further challenged the NCAA's amateurism rules, Jenkins v. National Collegiate Atbletic Ass'n and Alston v. National Collegiate Atbletic Ass'n. ${ }^{127}$ They were coordinated before

the defendants, Congress is the body to amend it, and not this court, by a process of judicial legislation wholly unjustifiable," 166 U.S. at 340. See Petition for Certiorari at 15, O’Bannon v. Nat'l Collegiate Athletic Ass'n, 137 S. Ct. 277 (2016) (No. 151167).

123 Plaintiff-Appellees' Petition for Rehearing En Banc, Nat'l Collegiate Athletic Ass'n v. O'Bannon, 802 F.3d 1049 (9th Cir. 2015), reh'g denied, No. 4:09-cv-03329CW (9th Cir. Dec. 16, 2015) (Nos. 14-16601, 14-17068).

124 The Plaintiffs submitted a petition on March 14, 2016. Petition for Writ of Certiorari, Nat'l Collegiate Athletic Ass'n v. O’Bannon, 137 S. Ct. 277 (2016) (No. 15-1167). The NCAA submitted a petition on May 13, 2016. Petition for Writ of Certiorari, Nat'l Collegiate Athletic Ass'n v. O’Bannon, 137 S. Ct. 277 (2016) (No. 15-1388).

125 O’Bannon v. Nat'l Collegiate Athletic Ass'n, 137 S. Ct. 277 (2016).

126 In its Petition for Certiorari, the NCAA showed its frustration with the current litigations: "The NCAA should not have to undergo a full trial (and years of litigation) or face treble damages whenever a plaintiff or counsel hits on a supposedly better way to administer college athletics." Petition for Writ of Certiorari at 26-27, O'Bannon, 137 S. Ct. 277 (No. 15-1388) (clarifying that the precedent would "preclude[ ] potentially endless antitrust challenges to NCAA rules").

127 In re NCAA Athletic Grant-in-Aid Cap Antitrust Litig., 375 F. Supp. 3d 1058 (N.D. Cal. 2019); In re NCAA Athletic Grant-in-Aid Cap Antitrust Litig., 311 F.R.D. 532 (N.D. Cal. 2015). The five power conferences are the Atlantic Coast Conference; Big 12 Conference; Big Ten Conference; Pac-12 Conference; and Southeastern Conference. The six other conferences are the American Athletic Conference; Conference USA; Mid-American Conference; Mountain West Conference; Sun Belt Conference; and Western Athletic Conference. The original Alston complaint was consolidated with four other complaints and a consolidated complaint was filed. Steve Berkowitz, Court Filing: NCAA, Conferences Say Scholarships Could Be Reduced, USA TODAY (May 1, 2015, 1:16 AM), http://www.usatoday.com/story/sports/college/ 2015/05/01/ncaa-suit-shawne-alston-martin-jenkins-kessler-nigel-hayes-claudiawilken/26685565/ [https://perma.cc/695Z-833L]. While Jenkins and Alston were coordinated for pretrial purposes in the Northern District of California before Judge 
Judge Wilken in the Northern District of California ("NCAA Grant-inAid"). ${ }^{128}$ The plaintiffs alleged that the NCAA and eleven athletic conferences systematically colluded to cap the compensation a school may provide athletes and sought to open compensation to the free market. ${ }^{129}$ These cases, accordingly, were broader than O'Bannon as they were not limited to NIL payments. Judge Wilken certified three classes: FBS football players, Division I men's basketball players, and Division I women's basketball players.

On March 8, 2019, after a bench trial, Judge Wilken held that the NCAA's rules capping the amount of compensation that student-athletes can receive in exchange for their athletic services violated the Sherman Act. Like she did in O'Bannon, ${ }^{130}$ she found that the NCAA rules were commercial, had anticompetitive effects, and were subject to the rule of reason analysis. Judge Wilken devoted most of her analysis to the asserted procompetitive justifications. This time, the defendants relied only on the two justifications that the Ninth Circuit in O'Bannon had upheld: the compensation rules promote (1) amateurism because it is a key part of demand for college sports and (2) integration of student-athletes with their academic communities because it improves the college education student-athletes receive. ${ }^{131}$

In analyzing the defendants' first purported pro-competitive effect, Judge Wilken expressed great frustration. She noted that the defendants

Wilken (the same Judge that decided O'Bannon), there is a significant difference between the cases. Jenkins sought only injunctive relief. Alston sought injunctive relief and monetary damages for four years (amount of time permitted under the applicable statute of limitations) of the difference between GIA and COA scholarships. Prior to trial, the damages portion of Alston was settled for approximately $\$ 208$ million. The injunctive portion of Alston went to trial. Jenkins was stayed. Order Denying Motion to Dismiss and Maintaining Stay on Jenkins, in re NCAA Athletic Grant-in-Aid Cap Antitrust Litig., 311 F.R.D. 532 (N.D. Cal. 2015) (No. 1200). Accordingly, the Jenkins case could still be remanded to New Jersey for trial.

128375 F. Supp. 3d 1058 (N.D. Cal. 2019).

129 NCAA Bylaw 15.1 as amended in 2015, provided that "[a] student-athlete shall not be eligible to participate in intercollegiate athletics if he or she receives financial aid that exceeds the value of the cost of attendance. . . ." NAT'L COLLegiate Athletic Ass'n, 2009-10 NCAA Division Manual 174 (2009).

${ }^{130}$ For a fuller discussion of Judge Wilken's decision, see Harrison (Buzz) Frahn, Michael R. Morey, Loren Shokes \& Omar Kanjwal, The Northern District of California Enjoins the NCAA From Capping the Amount of Education-Related Compensation that Student-Atbletes Can Receive, CaL. L. Ass'N (June 25, 2019), https://calawyers.org/ antitrust-ucl-and-privacy/the-northern-district-of-california-enjoins-the-ncaa-fromcapping-the-amount-of-education-related-compensation-that-student-athletes-canreceive/ [https://perma.cc/MGE4-XUE8].

131 In re Grant-in-Aid Cap, 375 F. Supp. 3d at 1098-1103. 
failed to offer "an affirmative definition of amateurism" and that "no link appears" between the "Principle of Amateurism" described in the NCAA's Division I Constitution and the challenged compensation limits: "the principle does not mention or address compensation; nor does it prohibit or even discourage compensation." 132 Judge Wilken expressed her concern that the defendants defined amateurism based on what it is not: the "only thing that can be inferred is that compensation constitutes 'pay for play' or 'pay' if the NCAA has decided to forbid it, and compensation is not 'pay for play' or 'pay' if the NCAA has decided to permit it." 133

Judge Wilken then analyzed whether the amateurism rules affected consumer demand and agreed with the plaintiffs that consumer demand, despite modifications in the rules permitting more benefits since O'Bannon, had not decreased. ${ }^{134}$ But she concluded, based mostly on anecdotal evidence, that:

when compared with having no limits on compensation, some of the challenged compensation rules may have some effect on preserving consumer demand for college sports as distinct from professional sports to the extent that they prevent unlimited cash payments unrelated to education such as those seen in professional sports leagues. ${ }^{135}$

As for the defendants' second pro-competitive justification, integration of athletes and other students, Judge Wilken dismissively rejected it, stating that considerable economic disparities already existed on college campuses due to students' socioeconomic backgrounds and other sources of wealth. ${ }^{136}$

Judge Wilken then turned to the third step of the rule of reason analysis: the plaintiffs' proposed less restrictive alternatives. She rejected the plaintiffs' "alternative that would prohibit the NCAA from placing any lim-

${ }^{132}$ Id. at $1098-99$.

133 Judge Wilken noted that the NCAA, in fact, permits "cash or cashequivalent compensation that exceeds the cost of attendance by thousands of dollars," some of which are "directly correlated with athletic performance" that would "appear, on their face, to be pay for play." Id. at 1099.

${ }^{134}$ Id. at 1100.

135 Id. at 1101 (emphasis added). Also, she found that "limits or prohibitions on most other benefits related to education that can be provided on top of a grant-inaid, such as those on tutoring, graduate school tuition, and paid internships, have not been shown to have an effect on enhancing consumer demand for college sports as a distinct product." $I d$. at 1102 .

${ }^{136}$ Indeed, Judge Wilken next explained that, if anything, the record supported that the challenged compensation limitations increased separation among students because they allowed schools to spend significant resources on opulent, athletes-only facilities. Id. at 1102-03. 
its on compensation or benefits, whether or not related to education, given in exchange for athletic services," ${ }^{137}$ noting (consistent with the Ninth Circuit's decision in O'Bannon) that unlimited cash payments unrelated to education would harm the demarcation between college and professional sports. ${ }^{138}$

Judge Wilken issued a rather complicated injunction. Basically, she permitted virtually every conceivable type of non-cash benefit as long as it was in some form or manner incidental or related to education ${ }^{139}$ but capped cash benefits for achievement in academics up to the value of those currently provided for team-based performance (commonly viewed to be up to $\$ 5,600$ over COA). ${ }^{140}$ Judge Wilken left in place the NCAA's rules that prohibit non-education-related cash compensation for individual athletic achievement. The injunction also allowed any NCAA member conference to impose stricter limits. $^{141}$

Both sides appealed to the Ninth Circuit and the oral argument was held on March 9, 2020. ${ }^{142}$ The panel was comprised of Judges Milan Smith, Gould, and Chief Judge Thomas, who wrote the partially dissenting opinion in O'Bannon and would have permitted the proposed $\$ 5,000$ payments for group NILs as long as they were held in trust for athletes until they leave school or graduate. ${ }^{143}$ Judge Smith was the only active questioner, including questions about the impact of CA SB 206 on the case. ${ }^{144}$ Seth Waxman,

137 Id. at 1086.

138 Id.

139 This included "computers, science equipment, musical instruments and other tangible items not included in the cost of attendance calculation but nonetheless related to the pursuit of academic studies; post-eligibility scholarships to complete undergraduate or graduate degrees at any school; scholarships to attend vocational school; tutoring; expenses related to studying abroad that are not included in the cost of attendance calculation; and paid post-eligibility internships." Id. at 1088.

${ }^{140}$ In re NCAA Athletic Grant-in-Aid Cap Antitrust Litig., No. 14-md-02541 CW, 2019 WL 1593939, at*1 (N.D. Cal. Mar. 8, 2019); see also Jenkins' Appeal Brief, supra note 42 at 11.

${ }^{141}$ More specifically, the injunction stated that the NCAA member conferences may "fix or limit academic or graduation awards or incentives that may be made available from that conference or its member schools to Division I women's and men's basketball and FBS football student-athletes on top of a grant-in-aid." In re Grant-in-Aid Cap, 2019 WL 1593939, at *1; see also Jenkins' Appeal Brief, supra note 42.

142 Alston v. Nat'l Collegiate Athletic Ass'n, No. 19-15566 (9th Cir. Mar. 9, 2020).

${ }^{143}$ O’Bannon v. Nat'l Collegiate Athletic Ass'n, 802 F.3d 1049, 1079 (9th Cir. 2015) (Thomas, C.J., concurring in part and dissenting in part).

144 Oral Argument, Alston, https://www.ca9.uscourts.gov/media/view_video.php ?pk_vid=0000017229 [https://perma.cc/Z7L6-YUGT]. 
attorney for the NCAA and conferences, stated that SB 206 is "flatly inconsistent" with the NCAA's principles of amateurism. ${ }^{145}$ Amateurism, as defined by the NCAA, continues to be the raison d'etre of its argument. In contrast, Jeffrey Kessler, one of the plaintiffs' attorneys, argued that the court should enjoin all NCAA restraints on compensation (which would allow the NIL compensation in SB 206). ${ }^{146}$ He stressed that the NCAA already, especially since O'Bannon was decided, permits benefits not related to education and consumer demand has only increased. ${ }^{147}$ He conceded that it would be appropriate to let the conferences respectively decide on appropriate limits. ${ }^{148}$ Based on the oral argument, it is unclear how the panel will rule; what is clear is that it is reasonable to expect at least one of the parties will petition for certiorari to the Supreme Court once the Ninth Circuit issues its decision.

In sum, these antitrust cases show the instability of the scope of amateurism and its relationship to consumer demand. Intercollegiate athletics, as discussed above, are increasingly commercial but still a hybrid model, containing elements of both professionalism and amateurism. There is much tension between these elements. Effective reform, including the payment for NILs, will move the system along the spectrum toward professionalism. But, as explained in Part V, we propose that the more defensible concern should focus on the difference between professionalism and the primacy of education in college sports.

\section{B. Claims to Rights of Publicity Are Inconclusive}

College athletes also have attempted to use right-of-publicity claims to obtain compensation for their NILs. Athletes have asserted their rights of publicity within antitrust lawsuits, as argued in O'Bannon, by alleging that the NCAA has agreed or conspired to refuse to pay for rights of publicity under the Sherman Act. Significantly, the Sherman Act permits treble damages and attorney's fees. ${ }^{149}$ Other times, athletes assert their rights of publicity claims directly.

Publicity rights, under common law or state statutory laws, protect a person's ability to control the use of their NIL for commercial gain. Thus, a right-of-publicity claim is an allegation of unauthorized misappropriation of

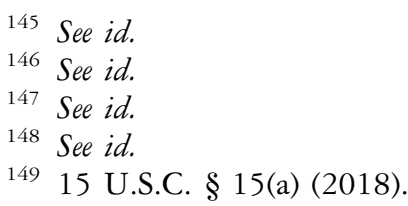


the commercial value of a person's identity. ${ }^{150}$ This right is generally recognized as not extending to use in newsworthy activities like news reporting or commentary, or in entertainment, creative works, or other transformative uses where the First Amendment is a defense to a right of publicity. ${ }^{151}$ Thus, athletes' rights to their own publicity vary depending on the respective state law, on how the athletes' NIL is employed, and on how much the athletes' likeness or character has been transformed. ${ }^{152}$

These issues were addressed by the Ninth Circuit in Keller v. Electronic Arts ${ }^{153}$ and by the Third Circuit in Hart v. Electronic Arts. ${ }^{154}$ Both courts held on motions that former college athletes had a right-of-publicity claim against Electronic Arts ("EA") based on the creation of avatars for the video game, NCAA Football, that looked like particular players, played like those players, and played in college stadiums that looked like those played in by those players. ${ }^{155}$ The defendants had not obtained permission from the players to use their images or likenesses, but argued that video games, like movie and books, are expressive works fully protected by the First Amendment. ${ }^{156}$ Both the Keller court and the Hart court rejected EA's defense that it had sufficiently transformed the avatars to have a First Amendment right to publish the video games without the players' permission and without compensating them. ${ }^{157}$ The courts noted that the avatars in the video games

150 See Restatement (Third) of Unfair Competition $\$ 46$ (Am. Law Inst. 1995).

${ }^{151} I d . \$ 46 \mathrm{cmt}$. C; see generally Marc Edelman, Closing the "Free Speech" Loophole: The Case for Protecting College Athletes Publicity Rights in Commercial Video Games, 65 FLA. L. Rev. 554 (2013); Eugene Volokh, The First Amendment, the Right of Publicity, Video Games and the Supreme Court, Wash. Post (Jan. 4, 2016, 3:30 PM), https:// www.washingtonpost.com/news/volokh-conspiracy/wp/2016/01/04/the-firstamendment-the-right-of-publicity-video-games-and-the-supreme-court/ [https:// perma.cc/ST5Y-DUNU]; Michael Marrero, A Primer On NCAA Atbletes' Right of Publicity, LAw360 (July 16, 2013, 12:49 PM), https://www.law360.com/articles/ 456776/a-primer-on-ncaa-athlete's-right-of-publicity [https://perma.cc/7K59DYZS].

${ }^{152}$ Specific analysis of rights of publicity, the First Amendment, federal and state consumer protection laws, copyright and trademark laws, fair use doctrines and federal and state tax laws as applied to institutions, athletes and donors is beyond the scope of this article.

153 Keller v. Elec. Arts, Inc., 724 F.3d 1268, 1276 (9th Cir. 2013). As noted Keller was consolidated with O'Bannon. See supra note 106.

${ }^{154}$ Hart v. Elec. Arts, Inc., 717 F.3d 141 (3d Cir. 2013); see also Daniels v. Fanduel, Inc., 909 F.3d 876 (7th Cir. 2018).

${ }^{155}$ Hart, 717 F.3d at 151; Keller, 724 F.3d at 1284.

156 Hart, 717 F.3d at 145; Keller, 724 F.3d at 1271.

157 Keller, 724 F.3d at 1271. 
were not sufficiently transformed; they were too accurate and faithful to reality. ${ }^{158}$

Chief Judge Thomas of the Ninth Circuit, like in O'Bannon, issued a dissenting opinion in Keller. He would have permitted EA's defense based on the First Amendment and would not have found that the athletes were entitled to publicity rights in the particular EA video football games. ${ }^{159} \mathrm{He}$ said that the players were unidentified and anonymous (despite the availability of third-party software that allowed gamers to determine the identity of the player), and stated that the game as a whole was sufficiently transformative. ${ }^{160}$

Significantly, in Keller, EA and the Collegiate Licensing Co., the NCAA's licensing arm, settled before trial for $\$ 40$ million, ${ }^{161}$ and the NCAA settled for $\$ 20$ million. ${ }^{162}$ As a result of the litigation, EA also agreed to stop producing its video games with avatars similar to former college athletes. Subsequently, the NCAA agreed to discontinue selling jerseys on its website with numbers of star athletes that matched the numbers used in games and school designations. ${ }^{163}$ Further, the NCAA said it would allow a blanket eligibility waiver for any currently enrolled student-athletes who receive funds connected with the settlement, adding "[i]n no event do we consider this settlement pay of athletics performance." ${ }^{64}$ Hart was wrapped into the settlement as well.

${ }^{158}$ Hart, 717 F.3d at 170; Keller, 724 F.3d at 1284.

159 Keller, 724 F.3d at 1284 (Thomas, J., dissenting). In O'Bannon, Chief Judge Thomas would have provided additional rights to athletes (up to $\$ 5,000$ held in trust) without specifying the particular submarket in which the revenues would be earned. O'Bannon v. Nat'l Collegiate Athletic Ass'n, 802 F.3d 1049, 1079 (9th Cir. 2015) (Thomas, C.J., concurring in part and dissenting in part).

160 Keller, 724 F.3d at 1288-90 (Thomas, C.J., dissenting).

161 Tom Farrey, Players, Game Makers Settle for \$40M, ESPN (May 30, 2014), https://www.espn.com/espn/otl/story/_/id/11010455/college-athletes-reach-40-million-settlement-ea-sports-ncaa-licensing-arm [https://perma.cc/GS6C-Y7T6].

162 Jon Solomon, NCAA Reaches \$20 Million Settlement With Players in Video Game Suit, CBS SPORTs (June 9, 2014, 8:15 AM), https://www.cbssports.com/collegefootball/news/ncaa-reaches-20-million-settlement-with-players-in-video-game-suit/ [https://perma.cc/YE8V-LEDZ].

163 Significantly, the dissent in Keller noted the inequity in a system wherein colleges, universities, coaches, television networks and others all make off the talent and hard work of athletes, many of whom come from inner city neighborhoods and rural towns, while the athletes are precluded from sharing in the revenues. Keller, 724 F.3d at 1289 , n.5 (Thomas, C.J., dissenting).

164 Jon Solomon, NCAA Reaches Settlement in EA Video Game Lawsuit, NAT'L ColLEgiate Athletic Ass'N (June 9, 2014, 10:53 AM), http://www.ncaa.org/about/resources/media-center/press-releases/ncaa-reaches-settlement-ea-video-game-lawsuit 
A broader discussion of whether college athletes have a right of publicity can be found in O'Bannon. The Ninth Circuit said that athletes have a right of publicity in the EA-produced NCAA football and basketball video games and, based on the realistic nature of the players, rejected the NCAA's argument that the First Amendment would preclude any publicity right for video games. Because it found that the athletes had standing and had suffered injury under the antitrust laws as a result of not being paid for their NILs in the video games, the Ninth Circuit declined to reach "the thornier questions of whether participants in live TV broadcasts . . . have enforceable rights of publicity or whether the plaintiffs are injured by the NCAA's current licensing arrangement for archival footage." 165 Notably, the District Court in O'Bannon ${ }^{166}$ stated that athletes would have a right to create and sell group licenses for the use of their NILs in live game broadcasts absent NCAA rules prohibiting such. ${ }^{167}$ District Judge Wilken specifically rejected the NCAA's defense that the First Amendment barred plaintiffs' claims.

[https://perma.cc/GMT7-HYV4]. It is easy to agree that the pay was not for performance on the field, but arguably it was pay for use of the athletes' NILs.

165 The court declined to consider NCAA's other argument that the Copyright Act preempts right-of-publicity claims. The court said this was irrelevant to the standing argument and other main issues of the case and is convoluted and complex. It did note that EA pays professional players in the National Football League ("NFL") and NBA for the right to use their NILs in its video games, indicating that the Copyright Act may not preempt such claims. O’Bannon v. Nat'l Collegiate Athletic Ass'n, 802 F.3d 1049, 1067 (9th Cir. 2015).

166 Two points to emphasize from O'Bannon that are relevant to this paper's proposal of NIL payments are that the allegations in the case involved payments from the NCAA or member institutions (not third parties) and only group licenses between the NCAA or member schools and the athletes (not third-party payments to individual athletes).

167 A case filed in 2017 by former football great, Chris Spielman, against Ohio State would have elucidated many of the issues left open in O'Bannon, but the case settled. Jennifer Smola, Spielman and Obio State Reach \$140k Settlement in Lawsuit Over Athletes' Images, Columbus Dispatch (Nov. 30, 2018, 10:02 PM), https:// www.dispatch.com/news/20181130/spielman-and-ohio-state-reach-140k-settlement-in-lawsuit-over-athletes-images [https://perma.cc/YUN8-492L]. There, Spielman, on behalf of a class of current and former Ohio State football players in federal court in Ohio (which is in the Sixth Circuit and not bound by the Ninth Circuit's opinion in O'Bannon), sued Ohio State; IMG, Ohio State's sports marketing agency; Nike, with whom Ohio State had a licensed apparel contract that included the sale of jerseys with former players depicted; and Honda, which sponsored banners at Ohio State with former players' names and photos. Spielman alleged that Ohio State unfairly profited from the use of the former players' NILs used on banners hanging at the school, sales of DVDs that showed replays of games and the sale of photos and jerseys. A year later and before much motion practice or discovery, the 
A few years later, in Marshall v. ESPN, ${ }^{168}$ the Sixth Circuit held differently. In Marshall, a group of Division I football and basketball players alleged that an agreement to force athletes to sign waivers of their otherwise existing right to compensation for their publicity rights for in-game broadcasts violated the Sherman Act. The Sixth Circuit held that the athletes did not have a cognizable right of publicity in the broadcast use of their likenesses. Significantly, Tennessee's right-of-publicity law had a carve out that stated, "it is deemed a fair use and no violation of an individual's rights shall be found . . . if the use of a name, photograph or license is in connection with a . . . sports broadcast or account." 169 Thus, the decision is limited due to the specific state law, although many states have similar laws. ${ }^{170}$

The NCAA's guidelines on NILs, as recently proposed and discussed in Part IV, directly caution that the new rules must account for athletes' rights of publicity and any defense of the First Amendment. ${ }^{171}$ As explained above, the applicability of these legal theories depends on the state in which the event occurs, the type of use (e.g., matters of public interest, like in-game live broadcast, versus commercial activities, like video games with players altered as avatars) and the extent of transformation of the images. ${ }^{172}$

\section{Employment Law Claims Have Failed to Yield Pay for College Atbletes}

Finding federal antitrust laws and rights of publicity insufficiently hospitable to their demands to be paid for their services, athletes have also resorted to employment law, seeking to categorize athletes as employees. Their efforts have thus far failed. For example, in Berger v. National Collegiate

parties settled. Spielman donated his settlement award of $\$ 140,000$ to charity. Speculation was that numerous similar lawsuits would be filed at other schools but perhaps due to the huge cost of litigation and loyalty by most athletes to their schools, we have seen no such explosion.

168 Marshall v. ESPN, 668 F. App'x 155 (6th Cir. 2016) (brought against two dozen entities including conferences, networks and licensing agencies; the NCAA was not sued).

169 Tenn. Code AnN. § 47-25-1107 (2019).

170 See supra notes 9-14. Also, to note is that the NCAA argued that California, in fact, has a state law that is similar to Tennessee law and protects live broadcasts as fair use, however, Minnesota where two of the plaintiffs lived did not have a similar law.

171 See infra Part IV.

172 Providing historical facts through game programs and video clips may command a substantial public interest and be a form of expression with First Amendment protection. Also, as noted earlier, copyright law recognizes that broadcast rights are held by the copyright owner. 17 U.S.C. § 106 (2018). 
Atbletic Ass'n, ${ }^{173}$ the University of Pennsylvania women's track and field athletes alleged that they were "employees" under the Federal Labor Standards Act ("FLSA") and were thus entitled to compensation for playing, similar to students who are compensated in work-study programs. In December 2016, the Seventh Circuit rejected this claim and held that, based on the revered tradition of amateurism, the athletes were not employees, emphasizing that intercollegiate sports are extracurricular "play" not "work." ${ }^{174}$ The concurring opinion, however, muddied the waters by stating that the economic reality and tradition of amateurism in revenue-producing sports like Division I men's basketball and FBS football may dictate a different result. ${ }^{175}$

In Dawson v. NCAA, ${ }^{176}$ the Ninth Circuit addressed the situation raised by the concurring opinion in Berger. The Ninth Circuit panel, which included Chief Judge Thomas (who would have permitted both the \$5,000 stipend in O'Bannon and the First Amendment defense in Keller, and who is now on the panel in GIA), held that FBS football players were not employees and therefore not owed a minimum wage or overtime pay. The court explained that the FLSA requires an analysis of the economic realities of the situation to discern the true nature of the parties' relationship. The court focused heavily on the fact that neither of the two defendants (the NCAA and the Pac-12 Conference) had the power to hire or fire Dawson, and then explicitly left open the possibility of similar claims succeeding against schools. ${ }^{177}$ Presumably, athletes would have to show that they do not al-

173162 F. Supp. 3d 845 (S.D. Ind. 2016).

174 This case originally was captioned Sackos/Anderson v. Nat'l Collegiate Athletic Ass'n. A former soccer player at the University of Houston alleged that the NCAA and DI universities conspired to violate the Fair Labor Standards Act by failing to at least pay a federal minimum wage of $\$ 7.25$ per hour. No. 1:14-cv1710-WTL-MJD (S.D. Ind. Oct. 22, 2014). Sackos was replaced by the women track and field athletes at the University of Pennsylvania as the plaintiffs. Berger v. Nat'l Collegiate Athletic Ass'n, 843 F.3d 285 (7th Cir. 2016). The District Court granted the defendants' motions to dismiss on February 16, 2016, and stated that the relationship between athletes and institutions of higher education is fundamentally an "educational experience," more akin to extracurricular student-run programs than to work-study programs. Berger, 162 F. Supp. 3d at 856.

175 Berger, 843 F.3d at 294.

176 Dawson v. Nat'l Collegiate Athletic Ass'n, 932 F.3d 905 (9th Cir. 2019).

177 Id. Failing in the Ninth Circuit, two months later, certain FBS football players brought a similar lawsuit in the Third Circuit. In November 2019, a former Villanova football player, Trey Johnson, filed a 116-page complaint in the Eastern District of Pennsylvania on behalf of a purported class of football players from 22 Division I schools (all located in the Third Circuit) against the NCAA. See Complaint, Johnson v. Nat'l Collegiate Athletic Ass'n, No. 2:19-cv-05230 (E.D. Pa. Nov. 6, 2019). In great detail, the complaint alleges that the NCAA failed to pay 
ready, through GIA and other benefits, receive the equivalent of the minimum wage.

\section{Efforts to Unionize Fail: Nortbwestern Football Players}

Yet another way in which college athletes have sought to obtain increased benefits, including pay, is through unionization. Specifically, a group of football players at Northwestern University, under the guidance of the College Athletes Players Association ("CAPA”), petitioned in 2013 to gain the right to unionize pursuant to the National Labor Relations Act ("NLRA"), seeking to gain similar rights to those held by professional athletes. ${ }^{178}$

The Regional Office in Chicago of the National Labor Relations Board ("NLRB"), after extensive briefing and a hearing, found that Northwestern (i) exerted great control over the athletes on issues including what they wore, where they traveled, when and how much they practiced, and (ii) received great benefits from the players (e.g., the Northwestern football program generated $\$ 30.1$ million in operating revenue during the 2012-13 season alone). ${ }^{179}$ The Regional Director concluded that the scholarship football players were "employees" and entitled to vote on whether to unionize and be represented for collective bargaining purposes by CAPA. ${ }^{180}$

the minimum wage to the athletes as required by the Pennsylvania Minimum Wage Act and the FLSA. The Plaintiffs assert that they are employees the same, or if not more so than, students in work study programs. The complaint alleges: "Notably, student ticket takers, seating attendants and food concession workers at NCAA contest are paid a minimum wage. . . under Work Study. At the same time, the Student Athlete, whose athletic work creates those Work Study jobs at the ticket gate, in the seats and at concession stands, are paid nothing." Ryan Boysen, NCAA Must Pay Minimum Wage, Ex-Villanova Player Says, LAw360 (Nov. 7, 2019, 5:31 PM), https://www.law360.com/articles/1217930/ncaa-must-pay-minimum-wage-ex-villanova-player-says [https://perma.cc/5GKE-92FE]. While this complaint does not address NIL payments, clearly any reasoning that compares non-athlete student pay to athlete pay is relevant.

${ }^{178}$ See Roberto L. Corrada, The Northwestern University Football Case: A Dissent, 11 HARV. J. OF SPORTS \& ENT. L. 15 (2020) (describing Northwestern University students' unionization efforts).

179 Professional players, through respective unions, negotiate collective bargaining agreements with owners and agree on restrictive commercial rules (e.g., player and team salary caps and reserve clauses) that otherwise would be prohibited under the Sherman Act.

180 Northwestern Univ. E College Atbletes Players Ass'n (CAPA), 13-RC-121359, 2014-15 NLRB Dec. P 15781, 2014 WL 1246914, at*13 (Mar. 26, 2014). 
This decision was heralded as a breakthrough for college athletes' rights, but this optimism was short-lived. The full NLRB overruled the regional director ${ }^{181}$ in an opinion that most view as a "punt." The NLRB chose not to address the merits of the matter, instead finding that unionization would not promote labor harmony. The NLRB made three key observations: (i) intercollegiate athletics was in a transitional phase in 2015; (ii) allowing unionization would have engendered systemic instability by only permitting unionization at the seventeen private colleges among 128 FBS schools; and (iii) there was a need to resolve the labor market issues and academic tensions in the current system. ${ }^{182}$ Significantly, the NLRB called on the United States Congress to clarify the institutional structure of college sports with a plea that it was addressing the "case in the absence of explicit Congressional direction regarding whether the Board should exercise jurisdiction," emphasizing that it was leaving open the issue of whether they might find jurisdiction in another case involving scholarship players. ${ }^{183}$

Notably, if athletes become "employees" under any of the scenarios above, schools will have to make payments for social security, workers' compensation, Medicare, unemployment insurance, and other benefits, along with pay; athletes will have to pay income and social security taxes on their compensation; and schools may lose some of their favorable Unrelated Business Income Tax ("UBIT") treatment by the IRS, along with other tax preferences. ${ }^{184}$ In the end, we believe that the educational budget and learning process will suffer from such a result. ${ }^{185}$

\footnotetext{
${ }^{181} I d$.

182 Northwestern Univ. E College Athletes Players Ass'n (CAPA), 362 N.L.R.B. 1350, 1368 (2015).

183 Id. at 1355 .

184 Subsequently, in August 2016, the NLRB held that graduate and undergraduate teaching and research student assistants were statutory employees pursuant to the National Labor Relations Act. Trustees of Columbia Univ. in the City of New York $\mathcal{E}$ Graduate Workers of Columbia GWC, UAW, 364 N.L.R.B. 90 (2016). Significantly, this decision overruled Brown Univ. E Int'l Union, United Auto., Aerospace E Agric. Implement Workers of Am., UAW AFL-CIO, Petitioner, 342 N.L.R.B. 483 (2004), a case that the NLRB in Northwestern said was distinguishable because "scholarship players bear little resemblance to the graduate student assistants." Northwestern had heavily relied upon Brown in its briefs. Northwestern Univ., 362 N.L.R.B. at 1365 .

185 See generally John D. Colombo, The NCAA, Tax Exemption, and College Atbletics, 2010 U. ILL. L. REV. 109 (2010).
} 


\section{The Potential Scope of NILs}

Athletes seek to sell their NILs to entities for a host of activities other than in-game broadcasts, including endorsements, advertisements, items of clothing with their names on them, appearing at clinics, appearing in video games, or commercializing an athlete's social media site. There is a lot yet to be determined regarding the application of NIL rights to these types of activities before college athletes are compensated. Consider the following:

- How will the eventual NCAA rulings or guidelines restrict athletes from receiving pay in exchange for their NIL rights? In its October 29, 2019 statement, the NCAA Board of Governors simply said that the three Divisions ${ }^{186}$ should develop rules that would permit NIL "benefits" for athletes without further elaboration of the term "benefits." 187 The District Court in NCAA Grant-In-Aid, while not directly addressing NILs, permitted unlimited benefits like laptops, smart phones, unlimited numbers of scholarships to graduate school, payment for semesters to study abroad and so on, as long as they are related to education, on top of (i) cash benefits up to $\$ 5,600$ that do not have to be related to education as long as they are team-based performance awards and (ii) cash benefits up to $\$ 5,600$ stemming from academic achievement awards. ${ }^{188}$ How this translates to NIL payments presents a host of complications. Such non-cash benefits are all potentially valuable, but, of course, they would be more valuable to some students than others.

- Will Division I seek to permit at least some cash payments as "benefits"? If so, will they require these payments be tethered to education, allowed while the student is still enrolled, or will the money accumulate in a trust fund, not available until after the athlete leaves school or graduates? Chief Judge Thomas in his dissent in O'Bannon would have required payments for group licenses to be held in trust and provided to the athlete once they leave school or graduate. $^{189}$

186 Eventually, if college athletes were paid, the astronomical compensation now paid to college coaches and athletic administrators likely would be reduced, alleviating some of the cost pressure. See the discussion in GURNEY ET AL., supra note 15, at chs. 7-8.

187 See NCAA NIL REPORT, supra note 7, at 3.

188 See id. at 4.

189 In re NCAA Athletic Grant-in-Aid Cap Antitrust Litig., 375 F. Supp. 3d 1058, 1099 (N.D. Cal. 2019). 
- If the new regime for NIL payments emanates from national legislation, in addition to the foregoing questions, will payments for NILs be restricted to non-game use of names, images, and likenesses? If so, what will be the scope of the restriction? Would commercials for in-game broadcasts and the like be allowed? In O'Bannon, the district court said that athletes have NIL rights for in-game broadcasts, while the Ninth Circuit specifically refused to address this-calling it a "thornier" question. ${ }^{190}$ Many states, like Tennessee in Marshall, as discussed earlier, have laws that explicitly exclude rights of publicity in live broadcasts. ${ }^{191}$ Plus, First Amendment rights, copyright laws and fair use standards may come into play to prohibit payments for in-game NILs. By contrast, NIL payments for names and rights of publicity on jerseys, likenesses in video games, endorsements on billboards, advertisements on social media, among others, are much more established. They are not live action. In most likelihood, any practical definition of NIL rights will be limited to non-game NIL rights.

- Will NIL rights be restricted to contracting with third parties, such that schools cannot contract with athletes either directly or as an intermediary? The potential implications here are twofold. First, if schools are involved in the contracting, then the school seemingly becomes similar to an athlete's employer. ${ }^{192}$ Second, if schools pay athletes directly for NILs, then Title IX would require parallel payments for women athletes.

- Even if third parties make the payments, would Title IX apply? If schools are involved-e.g., by administering, enforcing, or promoting the NIL contracts - or the payments are disguised as indirect recruiting efforts by schools, or if additional promotion efforts are provided to men and men's teams regarding the availability of NIL payments, then would Title IX apply like it does with fundraising efforts by third parties?

- If the schools pay out NIL money, how do they protect against growing financial deficits? Of course, the athletic department may lose some revenue in any case to the extent that companies substi-

${ }^{190}$ O'Bannon v. Nat'l Collegiate Athletic Ass'n, 802 F.3d 1049, 1080 (9th Cir. 2015).

191 Id.

192 See, e.g., Tenn. Code ANN. § 47-25-1107(a) (2019) ("It is deemed a fair use and no violation of an individual's rights shall be found, for purposes of this part, if the use of a name, photograph, or likeness is in connection with any news, public affairs, or sports broadcast or account."). 
tute athletes for whole programs as the vehicle to promote their products. ${ }^{193}$

- Will athletes be restricted as to when they can contract or activate their NIL rights? Will they have to do so only after the competitive playing season is over or only when classes are out of session? Can they do so as high school students?

- Will athletes be able to use university names, marks, and brands while exploiting NIL rights with outside companies?

- Will athletes on their social media that is being monetized be permitted to state that they play a certain sport at their respective schools?

- Will athletes be able to sign up with companies in competition with companies already in sponsorship deals with the school? What role will the compliance staff in athletic departments play in such evaluation?

- Should athletes be allowed to contract their individual NIL rights as well as join with other athletes to contract group NIL rights? The latter would apply, for example, to multiple athletes appearing in one advertisement, in one video game, or in a set of playing cards.

- Will the price that is paid to athletes for their NILs be regulated or will the total NIL income earned per year be bounded? ${ }^{194}$ Absent any restraints, it is easy to imagine an all-out competition of manipulated contracts among athletic department recruiters for star high school athletes. Consider this hypothetical: Big Ten schools from medium-sized Midwest cities contact various local businesses and arrange for these businesses to offer NIL contracts to prospects. The schools make a deal with these businesses, such as cheaper advertising space at the stadium or free luxury suite passes, if the businesses offer the school's top prospect $\$ 10,000$ for a public appearance to sign autographs that would normally fetch only $\$ 500$ in a competitive market. This type of behavior could quickly transform itself into a surrogate pay-for-play market. Some schools, particularly those in larger markets or a more lucrative conference, would gain another competitive advantage. Schools might find their sponsorship and luxury suite revenue from companies sacri-

193 See supra notes $185-86$ and accompanying text for tax implications to the employer (schools) and employees (athletes).

194 This substitution effect may be mollified if the popularity of college sports grows as a result of more fan interface with the athletes. 
ficed at the altar of this new, circuitous system of athlete compensation. To be sure, even if there is no such underhanded manipulation of market prices in the market for NILs, some schools in larger markets, such as the University of Southern California or the University of California, Los Angeles, will benefit over other schools in smaller markets, such as Oregon State University or Washington State University.

- Will the law permit athletes to unionize to help them identify opportunities and negotiate group NIL payments? Will athletes have a right to form trade associations to do the same?

- Will athletes have a right to hire agents to help them identify and negotiate NIL contracts? The NCAA's strict rules prohibiting agents, except in very narrow circumstances, could be an obstacle to athletes receiving expert advice. If agents are permitted, how would they be prevented from exploiting teenagers who are unsophisticated and inexperienced in business? If permitted, will athletes be allowed to contract with agents prior to their matriculation in college? If they are, then the agents could become surrogates for the university during recruitment and trigger open market competition.

The list of possible machinations and infelicitous outcomes is virtually endless. Clearly, there is a strong argument for imposing certain constraints on a newly emerged NIL marketplace. We suggest solutions to many of these concerns in Part $\mathrm{V}$, infra.

\section{THE NCAA's RECOMMENDATION FOR IMPLEMENTATION OF NIL PAYMENTS}

In response to the many pressures on the NCAA, including lawsuits, legislation, and the court of public opinion, the NCAA formed the NIL Committee, headed by Big East Commissioner Val Ackerman and Ohio State Athletic Director Gene Smith, to examine the feasibility of NIL payments to NCAA student-athletes. ${ }^{195}$ This committee, on October 29, 2019, presented an interim report to the NCAA Board of Governors that was

195 If they are so regulated, without an antitrust exemption, we are likely to see a continuation of lawsuits brought on antitrust grounds. Then the NCAA, no doubt, would argue that amateurism is a procompetitive justification for the restrictions. Even if the NCAA were successful, (which given the trend of the cases may not be likely), much time and money would be spent on the case(s). 
unanimously adopted. ${ }^{196}$ The interim report from the NIL Committee and the Board's affirmative vote on the report potentially represent a turning point in the NCAA's definition of and insistence on amateurism. Still, there remains great uncertainty around the report's details, which will be further detailed in April 2020 when the NIL Committee presents its second report to the Board of Governors.

The momentous report stated that "[i]t is the policy of the Association that NCAA member schools may permit students participating in athletics the opportunity to benefit from the use of their name, image and/or likeness in a manner consistent with the values and beliefs of intercollegiate athletics." 197 The Board voted that each of the three Divisions should modify and modernize the relevant NCAA bylaws and rules and:

- Ensure student-athletes are treated similarly to non-athlete students unless a compelling reason exists to differentiate.

- Maintain the priorities of education and the collegiate experience to provide opportunities for student-athlete success.

- Ensure rules are transparent, focused, and enforceable and facilitate fair and balanced competition.

- Make clear the distinction between collegiate and professional opportunities.

196 There is additional pressure to pay athletes for their NILs due to the limited options that high school students have to play professional sports upon graduation. Indeed, both high school and college athletes with dreams of going professional are subject to entry rules created by the different professional leagues, e.g., the NBA's "one-and-done" rule or the NFL's requirement that athletes be out of high school for three years or the MLB rule that allows athletes after high school but once enrolled in college, they must remain until they complete their junior year or reach 21 years of age, unless they attend junior college in which case they can enter the draft after two years. Kelly Hines, Going Pro: Which Sport Gets Draft Rules Right?, Tulsa World (Apr. 20, 2013), https://www.tulsaworld.com/sportsextra/collegebasketball/going-pro-which-sport-gets-draft-rules-right/article_ea5642ca-4a94-5084bd1f-f3f3213cbec3.html [https://perma.cc/96P7-QWAL]. The NBA rule, in particular, requiring just one year post-high school before receiving eligibility, has received a lot of negative attention because, for the elite players who would otherwise go straight into the NBA, they are forced to either play in the NCAA, patronizing the notion of primacy of education, play with the NBA's developmental league, or play with professional teams located overseas. The NFL does not have a significant international market so athletes out of high school have few choices but to enter college, risking serious injury, if they wish to one day turn professional. See NAT'L Collegiate Athletic Ass'n, Federal and State Legislative Working Group REPORT TO THE NCAA BOARD OF GOVERNORS 2 (2019) thereinafter NCAA NIL WORKING GROUP REPORT], https://ncaaorg.s3.amazonaws.com/committees/ncaa/ exec_boardgov/Oct2019BOG_Report.pdf [https://perma.cc/R3CF-J8UQ].

${ }^{197}$ See NCAA NIL REPORT, supra note 7 , at 3. 
- Make clear that compensation for athletics performance or participation is impermissible.

- Reaffirm that student-athletes are students first and not employees of the university.

- Enhance principles of diversity, inclusion, and gender equity.

- Protect the recruiting environment and prohibit inducements to select, remain at, or transfer to a specific institution. ${ }^{198}$

Attempting to control the future modifications, the NIL Committee provided more "guidance" in its report to the Board. ${ }^{199}$ The guidance appears to stem from the cases discussed above, including that payments be tethered to education (as in O'Bannon and NCAA Grant-in Aid), that athletes not be employees and not be compensated for their athletic performances (as in the FLSA and NLRA cases), and that First Amendment rights of third parties be considered (as in Keller, Hart, and Marshall).

The NIL Committee made a point of noting that the NCAA's current bylaws permit athletes to engage in outside employment and business activity. ${ }^{200}$ The NIL Committee then provided examples of situations in which NIL payments might fit under the current bylaws but could also conceivably be used unfairly to compensate an athlete directly or indirectly for participation in athletics or involve inappropriate payments by boosters and therefore should be prohibited. The examples of possible acceptable use include athletes using their NILs in connection with writing and publishing a book or charging a fee for a lesson that is unrelated to sports; creating a social media channel to serve as the platform for their own business; promoting their own nonprofit organization; and creating and producing a video series containing nutritional tips for athletes and distributing the content via social media. ${ }^{201}$

The NIL Committee also said that each of the NCAA's three Divisions should develop their own rules and consider, inter alia, whether the rules require that athletes must receive prior approval from the athletic director, faculty athletics representative, or their designee for NIL payments, and whether there must be no involvement of schools, employees, or boosters in the development or promotion of NIL opportunities. ${ }^{202}$

While commentators and member institutions are generally optimistic about these potentially important changes, many are quick to note that the

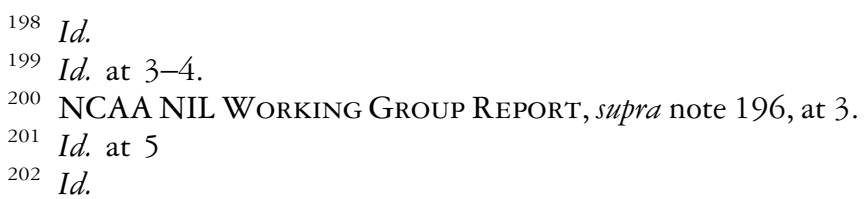


"devil is in the details." 203 The final proposals will need to be very specific, especially to avoid unintended consequences. We believe that the NIL Committee has taken a useful step forward in suggesting guidelines. ${ }^{204}$ Our biggest concerns are with the following suggestions:

- Athletic department approval must be required.

- All deals must not relate to athletics and must be tethered to education.

- Schools can make NIL payments to athletes.

- All compensation for athletic performance or participation, even outside the school arena, is impermissible.

- The availability of cash payments for NIL use may be prohibited as the report refers only to "benefits" that can be received.

Directly addressing these concerns, we believe:

- Athletic departments should not play a role in approving NIL payments but instead should receive copies of proposed NIL deals only to determine whether they conflict with the school's current contracts. Congress should appoint an independent commission to set appropriate restrictions; analyze the impact, including unintended consequences, of the new rules; and act as a clearinghouse.

- Athletes should have complete control over receiving payments for their own NILs, including use of or reference to their athletic abilities (e.g., basketball players can autograph a picture of themselves dribbling a basketball). One exception is that, as explained infra, there should be reasonable restrictions set by the independent commission, including the annual dollar amount of payments on local contracts per individual to protect the primacy of education and to ensure that the payments are not disguised recruiting bonuses or other improper payments. Further, athletes should not be restricted to receiving only payments that are tethered to education. As demonstrated during the trial in NCAA Grant-in-Aid and the District's Court extremely complicated injunction, such tethering is artificial, unnecessary, very limiting, and entirely unworkable, and

203 Id.

204 See, e.g., Greg Hunter, Lyons Addresses Ever-Changing Landscape of College Atbletics, Morgantown News (Nov. 30, 2019), https://www.wvnews.com/morgantownnews/sports/lyons-addresses-ever-changing-landscape-of-college-athletics/ article_db3bdc30-efa1-53e7-ac46-a54dd5f9c046.html [https://perma.cc/J4BVW5L4] (interview with Shane Lyons, Chairman of the NCAA Division I Football Oversight Committee and West Virginia University Director of Athletics). 
would constitute restrictions that are not applied to other students. For example, is a car used to drive to school related to education? ${ }^{205}$

- Schools should not engage in paying athletes directly or indirectly for their NILs. Such behavior would bring the relationship between the school and athletes closer to an employer/employee relationship with all the attendant consequences. Also, it would raise questions regarding schools' UBIT responsibilities and other tax issues. College athletes should not be permitted to be professional athletes, employed by professional leagues, while eligible for college sports but otherwise, should not be restricted from receiving payment at the going market rate for participation in athletics outside of school.

- Athletes should be permitted to receive cash as one form of benefit. They already receive cash, through COA stipends, of which use is not regulated. ${ }^{206}$

\section{A Proposal for Federal Implementation OF NIL Rights 207}

In this section, we propose a detailed framework for the payment to college athletes for their NILs. ${ }^{208}$ The framework includes principles and

205 In November 2019, the NCAA released a timeline for schools and divisions to provide feedback and prepare for the future rules. Key dates are: April 2020_ Working Group Second Report to Board of Governors due; September 2020Deadline for Divisions II and III Presidents to sponsor legislation; November 2020_-Deadline for Division I to submit proposals; January 2021—discussion at the NCAA Convention of the proposals. Notably there is no deadline for Division I to sponsor legislation, although the NCAA notes that the Division I legislative process allows the Division I Board of Directors discretion to adopt legislation at any time. In fact, there is no deadline for voting on the proposals. See NCAA NIL REPORT, supra note 7, at 4.

206 This would help better resolve situations like that of University of Central Florida backup kicker, Donald De La Haye, who lost his eligibility after refusing to stop monetizing his YouTube channel. See Dan Gartland, UCF Kicker Ruled Ineligible After YouTube Channel Gets Him in Trouble with NCAA, SPORTs ILlustrated (July 31, 2017), https://www.si.com/college/2017/07/31/ucf-kicker-donald-de-la-hayeineligible-ncaa-youtube-videos [https://perma.cc/NB7D-F8WF]. The NCAA based its decision on the fact that there were football-related videos on the channel. See id. Even United States Senator Marco Rubio tweeted "The @NCAA is out of control," in response to this decision. Marco Rubio (@marcorubio), TwitTer (Aug. 1, 2017, 7:58 AM), https://twitter.com/marcorubio/status/892353886589116417 [https:// perma.cc/MG5M-VMMQ]

207 See Mandell, supra note 34.

208 This proposal is similar to the Drake Group Position Paper. Compensation of College Athletes Including Revenues Earned from Commercial Use of Their Names, Image 
conditions for both institutions and athletes and a proposal for an independent Commission that would set specific standards and adjudicate compliance with those standards.

\section{A. Guiding Principles}

We propose that intercollegiate athletics operate according to the following basic principles and rules:

- College athletes should be treated like other students as much as possible with regard to their independent efforts to engage in non-school efforts to receive payments for their NILs.

- Extracurricular activities generally, and intercollegiate athletic programs particularly, are important contributors to student development. ${ }^{209}$

- Higher education institutions should have the right to own and commercially benefit from performance events involving students participating in the institution's curricular and extracurricular activities through the sale of tickets, parking, game, or event programs, posting on the school's social media accounts, advertising, and sponsorship rights, and rights to live and delayed electronic telecasts. The revenues from such activities should be used to defray the costs of the extracurricular activity or otherwise advance the mission of the nonprofit higher education institution, including caring for the health and welfare of participants.

- College athletes should not be permitted to use the logos, brands or marks of their institution for private gain. But, under fair use, they should be able to reference the fact that they are athletes at their respective school. College athletes should otherwise have the right to use their NILs for private gain conditioned on the athlete obtaining such opportunity without assistance from the institution (i.e., such activities are not arranged by employees or others engaged by the athlete's institution for that purpose) and other conditions that protect the primacy of education.

\footnotetext{
and Likenesses and Outside Employment, Drake Group (Nov. 4, 2019), https:// www.thedrakegroup.org/2019/10/14/compensation-of-college-athletes-includingrevenues-earned-from-commercial-use-of-their-names-images-and-likenesses-andoutside-employment/ [https://perma.cc/8BU2-8NBU]. The position paper provides considerably more detail for a proposed solution.

209 This framework is most applicable for Division I athletes and can be easily modified for Divisions II and III, if necessary. Given that our proposal does not permit institutions to pay athletes, no modification may be necessary.
} 


\section{B. Specific Proposal}

\section{Higher Education Institution Use of Athlete NILs}

Higher education institutions should be permitted to condition participation in their athletic programs upon athletes providing the limited use of their NILs related to such participation. Such limited use shall include:

- Audio or videocast or otherwise recorded for live or delayed electronic distribution or photographed for print or digital publication of the regular season (including post-season) athletic events in which the athlete is participating during that season.

- Advertising or promotion of the regular season and post-season athletic events in which the athlete is participating during that season.

- Publication and sale of event programs sold with or during the regular season and post-season at athletic events in which the athlete is participating during that season.

- Perpetual print and electronic publication rights for the athlete's historical performance and participation statistics and photographs of prior champions or championship teams which may not be commercially exploited in any way other than athletic event programs. Such historical license should not extend to commercial documentary products that exist separate from the current athletic event. The inclusion of historical data on the institution's official athletics internet site which may be supported by sponsorship revenues shall not be considered prohibited commercial exploitation.

- Official team apparel or equipment to teams or to be the exclusive seller of such products at official athletic events and activities in which the athlete is participating. ${ }^{210}$ Athletes' obligations to wear official team apparel shall extend throughout the academic year for official team practices, exhibition or non-traditional season contests, and appearances at official university events in which this apparel must be worn by all attending players.

Other conditions on institutions that we propose are:

- Higher education institutions should be prohibited from otherwise exploiting current students' NILs (other than as detailed above for official

210 See College Extracurricular Activities - Impact on Students, Types of Extracurricular Activities, StateUniversity.COM, http://education.stateuniversity.com/pages/1855/ College-Extracurricular-Activities.html\#ixzz3RYLjNs8c [https://perma.cc/VSE9V7D8]. 
team events and activities) such as entering into licensing agreements using student NILs for video games, licensed apparel, licensed products, and more.

- The NCAA, athletic conferences, and member schools can jointly license their regular season and post-season collective intellectual property (NCAA, school, and conference names, marks, logos, and more) to third parties, conditioned on such agreements not including royalty or other payments to athletes.

- Any rules that schools or conferences employ regarding restrictions on social media usage during athletic contests, travel, or any other official team events will continue to apply. ${ }^{211}$

\section{College Athlete Independent Use of Own NIL}

College athletes should be permitted to obtain employment and accept pay for the commercial use of their NIL in advertisements, appearances, or speaking engagements, and for endorsement of commercial products ("commercial arrangements") with certain conditions:

- College athletes (or their agents) must independently obtain such arrangements (such arrangements cannot be made, directly or indirectly, by the institution's employees, donors, athletic program sponsors, or advertisers, or other representatives of its athletics' interests). ${ }^{212}$

- College athletes' commercial arrangements must not conflict with the institution's rights as specified above for official team events or activities. This shall not preclude a college athlete's agent or the athletes themselves from independently soliciting work from any company that also supports the institution.

- College athletes may earn pay for work performed but are limited by the maximum imposed by the NIL Commission (discussed infra), including for work related to the athlete's skill and notoriety and NIL agreements related to endorsements, product licensing, personal appearances, books,

211 Athletes shall retain the right to use their own sports equipment. Shoes are subject to a medical exception, in which case, athletes shall be required to cover the brand of the conflicting sponsor during participation if during such regular season (including post-season) athletic events.

212 See, e.g., Marc Stein, NBA Social Media Guidelines Out, ESPN (Sept. 30, 2009), https://www.espn.com/nba/news/story?id=4520907 [https://perma.cc/WY8PS3SL] (explaining that the NBA introduced a policy prohibiting players, coaches and team personnel from using electronic communication devices and accessing social media beginning forty-five minutes before the start of a game and only concluding after players and coaches have completed their post-game media obligations). 
movies, television, or radio shows, providing autographs, endorsing commercial products, or being the owner or partner of a sports business, among others.

- College athletes may not enter into NIL arrangements with third parties that are inappropriate as determined by the Commission with respect to the character and integrity of the third party and the type of the activity.

- College athletes must report, in writing, their NIL arrangements above a de minimis amount set by the Commission and submit such arrangements to both the school and the Commission or entity such as an Eligibility Center. ${ }^{213}$

- College athletes must adhere to the standards set by the NIL Commission including the maximum annual local income based on going market rates that can be earned from the arrangements.

- College athletes must be in good academic standing, meeting all rules related to athletics' eligibility, including normal progress and full-time enrollment provisions.

- College athletes may enter into group licensing agreements with other athletes. Such group agreements shall also conform to the policies above. $^{214}$

- College athletes may hire agents and lawyers without impacting their eligibility.

3. An Independent Commission Should Set Appropriate Standards for NIL Payments to Athletes

Congress should establish an independent NIL Commission to set standards for the payment of college athletes' NILs. ${ }^{215}$ Higher education has an important obligation to promulgate rules that place a student's academic

213 Marketing companies are jumping at the opportunity to assist college athletes to monetize their NIL rights either individually or as a group. See Michael Smith \& Liz Mullen, College Sports: Sharper Resolution, SpORTs Bus. J. (Dec. 2, 2019), https://www.sportsbusinessdaily.com/Journal/Issues/2019/12/02/In-Depth/NIL.aspx [https://perma.cc/D7N9-C3J8].

${ }^{214}$ See generally Gabe Feldman, The NCAA and "Non-Game Related" Student Athlete Name, Image and Likeness Restrictions, KNIGHT COMmission ON INTERCOLLEGIATE Athletics (May 2016), https://www.knightcommission.org/wp-content/ uploads/2008/10/feldman_nil_white_paper_may_2016.pdf [https://perma.cc/ 23RX-UTZH] (proposing numerous restrictions, many of which are similar to those suggested here but also proposing group licensing arrangements between schools and athletes in addition to individual agreements between athletes and third parties).

${ }^{215}$ Id. 
success above the athletic success of its sports teams. The proper limitations that permit students to engage fully in athletics and to complete academic requirements for a degree, while also using their NILs for payment, can best be developed and enforced by an independent commission that does not also have the competing objective of creating winning athletic teams.

\section{a. Standards}

We suggest the independent NIL Commission be charged with the following:

- Set the maximum income based on going market rates that can be paid to athletes for use of their NILs on an annual, local basis. ${ }^{216}$ Absent such control, the NIL market runs the risk of devolving into a surrogate labor market where colleges will approach high school recruits with financial packages based on promised NIL contracts. ${ }^{217}$

- Set standards related to the appropriateness of college athletes' required activities, including a requirement that no classes, exams, or participation in other required academic activity be missed to perform agreement-related activities. ${ }^{218}$

- Set standards for the character and integrity of any third party which shall not be more onerous than the NCAA's advertising and promotional standards.

- Set standards for the registration and recognition of college athlete approved sports agents.

- Set standards for agents and attorney agreements that specify recommended ranges for hourly rates or percentage commissions.

216 The NIL Commission should consider establishing a clearinghouse for NILs that could be similar to the NCAA's current Eligibility Center or the Drug Free Sport International. All athletes could be required to submit their NIL agreements to the clearinghouse for review. Also, the agreements would be posted on a website that is searchable. This transparency hopefully will help reveal potential abuses. The Commission could set appropriate standards for the redaction of competitively sensitive information as long as such redaction does interfere with the purpose in making the contracts publicly available.

${ }_{217}$ It is important to control local, as opposed to national, income because it is local income that enters into consideration during athlete recruitment. Local would be delineated by a mile radius around the university, with an exception for social media income which, while generated locally, can engage national sources of revenue. We believe that those athletes with a national reputation should be able to fully exploit their notoriety nationally without limitation.

218 Also setting a cap on the amount that athletes can earn from local sources may minimize the concern that donations made directly to schools will be reduced, which in turn could particularly impact non-revenue sports. 
- Set a value (e.g., $\$ 1,000)$ that is considered de minimis for reporting purposes.

- Collect all non-de minimis NIL arrangements and make them publicly available.

- Receive and monitor complaints concerning agents, attorneys, and other third parties related to compliance with the standards set by the Commission.

- Adjudicate generally compliance with its standards. ${ }^{219}$

\section{b. Composition of the NIL Commission}

The NIL Commission shall consist of a majority of independent experts. At least one independent member shall be appointed by each of the Faculty Athletic Representatives Association, the National Association for Athletics Compliance, the National Association of Collegiate Directors of Athletics, the Sports Lawyers Association, CAPA, and the Association of Sports Economists. The term "independent" shall mean at least two years removed from employment by the NCAA, a NCAA member athletic conference, or a member institution athletic department. The member must also agree not to return to this employment within two years of leaving the NIL Commission.

\section{c. A Necessary Antitrust Exemption}

The NIL Commission could effectively operate only if Congress (and the NCAA to the extent that its rules require athletes to abide by the NIL Commission's requirements) grants it a limited and conditional antitrust exemption. ${ }^{20}$ A limited antitrust exemption would specifically permit implementing the above standards. ${ }^{221}$ These controls are necessary to achieve the prioritized purposes of higher education in the conduct of intercollegiate athletics. Further, the exemption would eliminate any restrictions and ambi-

219 The authors have considered other restrictions, including limitations on the amount of time that athletes may devote to NIL profiting activities and the number of these activities. While it may be something that the Commission in the future finds desirable, we do not suggest such regulations at this time.

220 These activities could be delegated to the clearinghouse discussed earlier. See supra note 217. We do not envision the Commission initiating such adjudication, as the burden would be too great. Rather, we suggest that certain designated third parties could bring appeals that would be adjudicated by the Commission.

221 Ideally, Congress would consider a limited Commission and conditional antitrust exemption that would be much broader and address holistically all the key reforms needed in college sports. See generally Meyer \& Zimbalist, supra note 68. 
guity resulting from the current cases, including those from O'Bannon and NCAA Grant-in-Aid.

If an antitrust exemption is granted that allows the setting of market restraints, such as caps on local NIL income, then we believe the exemption should also apply to setting caps on coaches' and administrators' income. As discussed above, the extraordinary income paid to Division I football and basketball coaches results largely from the suppression of pay to athletes. It would be unconscionable to pass an exemption permitting the capping of local athlete NIL income, while not permitting the capping of coach and administrator income.

The exemption would also allow for the establishment of uniformity of rules regarding agreements on NIL rights for live in-game broadcasts that are now dependent on underlying common law and statutory law. ${ }^{222}$

A limited and conditional antitrust exemption that applies to the legitimate categories of controls discussed in this proposal will enable the NIL Commission and the NCAA collectively to enact needed reforms without fear of future legal liability. Such an exemption is both justifiable and necessary. Antitrust lawsuits represent huge costs for legal representation, participation in court cases, and payment of damages. ${ }^{223}$ These funds would otherwise be available to advance the NCAA's and its member institutions' nonprofit educational purposes.

A solution that includes an antitrust exemption would not be extraordinary. ${ }^{224}$ Congress has enacted limited antitrust exemptions in many

${ }^{222}$ An Act of Congress that creates a national NIL Commission and grants a federal antitrust exemption would preempt state laws that attempt to regulate NILs.

${ }^{223}$ Interestingly, the NCAA no longer requires athletes to sign Form 15-3(a) in which athletes agreed to give up any NIL rights they might have regarding broadcasts and promotions thereof. This is consistent with the argument made by the NCAA at the oral argument on behalf of the summary judgment motion in Keller, at which the NCAA's attorney stated: "[T] rights in the live broadcasts of the games." He explained that live broadcasts are noncommercial events, noncommercial speech that involves a matter of public interest. Reporter's Transcript of Proceedings at 31, Keller v. Elec. Arts, Inc., 4:09-cv-01967 CW (N.D. Cal. Aug. 18, 2015).

${ }_{224}$ Noteworthy is that antitrust damages are trebled under the Sherman Act. See 15 U.S.C. $\S 15$ (2018). This is an impetus for the parties to reach a settlement. Settlements resolve matters only between the particular parties and do not foreclose future cases brought by a different set of plaintiffs. See, e.g., White v. Nat'l Collegiate Athletic Ass'n, No. CV 06-0999-RGK, 2006 WL 8066803 (C.D. Cal. Oct. 19, 2006) (discussing allegations regarding the GIA Cap that settled, allowing for a different set of plaintiffs in O'Bannon to bring similar allegations without the existence of contrary precedent). 
industries-ranging from the hog industry, ${ }^{225}$ to railroads, ${ }^{226}$ to soft drinks, ${ }^{227}$ to the insurance industry, ${ }^{228}$ to professional sports, ${ }^{229}$ and, most significantly, to higher education. ${ }^{230}$ Statutory antitrust exemptions involving the sports industry or higher education include (a) The Sports Broadcasting Act of 1961 ("SBA"), which provides limited immunity from antitrust litigation to the four major professional sport leagues for selling horizontally pooled broadcasting rights to over-the-air channels; ${ }^{231}$ (b) a narrow and targeted antitrust exemption in 1966 that permitted the combination of the National Football League and American Football League; ${ }^{232}$ (c) the Ted Stevens Olympic and Amateur Sports Act in 1978 (subsequently amended in 1998), which created a vertical structure for the management of certain amateur sports in the United States; ${ }^{233}$ (d) the Curt Flood Act of 1998, which removes Major League Baseball's presumed antitrust exemption (judicially conferred in 1922) in the area of labor relations, ${ }^{234}$ (e) the Improving America's Schools Act of 1994, which exempts from antitrust laws agreements to admit students on a need-blind basis by institutions of

225 Arguably, regulating college athletics including eligibility, scholarships, scheduling and spending is not so different from regulating college financial assistance such as covered in the Higher Education Act that includes rules on loan limits, accreditation, determining who gets money, how much and when, etc. And, regulating gender equality in college sports, e.g., 20 U.S.C. $§ \S ~ 1681-1688$ (2018), demonstrates that Congress believes it is appropriate to impose legislation in this important area.

226 Anti-Hog-Cholera Serum and Hog-Cholera Virus Act, 49 Stat. 781 (1935) (codified at 7 U.S.C. $\$ 852(2018)$ ).

227 ICC Termination Act of 1995, Pub. L. No. 104-88, 109 Stat. 812 (codified at 49 U.S.C. $§ 10706$ (2018)).

${ }^{228}$ Soft Drink Interbrand Competition Act, Pub. L. No. 96-308, 94 Stat. 939 (1980) (codified at 15 U.S.C. $\$ \$ 3501-03$ (2018)).

229 McCarran-Ferguson Act, 59 Stat. 33 (1945) (codified at 15 U.S.C. $\S \S 1011-15$ (2018)).

230 See infra notes $233-237$.

231 See infra notes 237-238.

232 Sports Broadcasting Act of 1961, Pub. L. No. 87-331, 75 Stat. 732 (codified as amended at 15 U.S.C. $\$ 1291$ (2018)) (stating, "[t $[$ he antitrust laws, as defined in section 1 of the [Sherman] Act[,] . . . shall not apply to any joint agreement . . . by which any league of clubs participating in professional football, baseball, basketball, or hockey contests sells or otherwise transfers all or any part of the rights of such league's member clubs in the sponsored telecasting of the games ... . engaged in or conducted by such clubs").

233 Pub. L. No. 89-800 § 6(b)(1), 80 Stat. 1515 (1966) (codified as amended at 15 U.S.C. $\S 1291$ (2018)).

234 Ted Stevens Olympic and Amateur Sports Act, Pub. L. No. 105-225, 112 Stat. 1466 (1998) (codified as amended at 36 U.S.C. $\$ \S 220501-220512$ (2018)). 
higher education; ${ }^{235}$ and (f) the Medical Resident Matching Program Exemption in $2004 .^{236}$

These Acts demonstrate that Congress protects certain activities in sports and higher education from the antitrust laws when it deems fit. It defines antitrust exemptions specifically and narrowly. Here, too, the exemption should be narrowly defined.

\section{CONCLUSION}

In this Article, we have reviewed the legal history of amateurism in collegiate sports and its relationship to NILs. The Keller and O'Bannon cases brought the NIL issue to the fore and the September 30, 2019, signing of the California Fair Pay to Play Act by Governor Newsom broke the longstanding legislative inertia surrounding NCAA amateurism. Threatened with losing control over NIL and broader compensation issues, on October 29, 2019, the NCAA Board of Governors relented and suggested, at least nominally, that the NCAA's enduring prohibition on athlete compensation from NILs be changed.

While the Board did not announce specific measures to implement NIL rights for athletes, it did charge each of the NCAA's three Divisions with proposing guidelines for implementation by January 2021. These guidelines are to be consistent with the NCAA's conception of amateurism and only allow "benefits" that are tethered to education.

We critique this approach as far too narrow and failing to grant college athletes the same NIL rights as granted to other students (with a few exceptions). The NCAA has applied a constantly morphing definition of amateurism over the years. The only sensible definition of amateurism for a college

23515 U.S.C. $\$ 26 \mathrm{~b}$ (2018). Congress ensured the limited scope of its intervention by expressly stating that, "the passage of this Act does not change the application of the antitrust laws in any other context or with respect to any other person or entity." Curt Flood Act, Pub. L. No. 105-297, § 2, 112 Stat. 2824 (1998). The Supreme Court had previously presumed that Major League Baseball was exempt from the antitrust laws. See Fed. Baseball Club v. Nat'l League, 259 U.S. 200 (1922).

236 Improving America's Schools Act of 1994, Pub. L. No. 103-382, tit. V, $\S 568(a), 108$ Stat. 4060) (codified at 15 U.S.C. $\$ 1$ (2018) (note)) The Act permits, inter alia, schools jointly "to use common principles of analysis for determining the need of such students for financial aid if the agreement to use such principles does not restrict financial aid officers . . . in their exercising independent professional judgment with respect to individual applicants for such financial aid." The Act does not permit schools to agree on which particular students are entitled to aid. 
athlete would require that athletes not be paid by member institutions a cash income for playing their sport.

Accordingly, we propose a NIL policy that affords many more opportunities for college athletes. Athletes should have the same right to be paid by third parties as other students, save for a few narrow exceptions. Importantly, NIL income contracted with third parties should not conflict with students' pursuits of a college education. ${ }^{237}$ Any difference that persists between students who are not athletes, on the one hand, and students who are athletes, on the other hand, is necessary due to the extraordinary time demands placed on athletes. ${ }^{238}$ To ensure both that our more open system does not ignore athletes' abilities to attend and study for their classes and that a surrogate, indirect pay-for-play system does not evolve, it is necessary to impose a regulatory structure. Such a structure would be most effective if it were mandated by Congress and were independent. Unfortunately, the oversight structure means a modicum of bureaucracy. ${ }^{239}$ While it would be desirable to have a world where no regulatory controls were necessary, we do not live in such a world, and the challenge then becomes not to abolish regulation, but to make it function effectively.

237 15 U.S.C. $\$ 37$ (2018).

238 See supra Part III for a few other narrowly drawn circumstances where third party NIL income may be restricted to ensure no conflicts with the school's intellectual property.

239 It is recognized that athletic departments that earn revenues from broadcasts and apparel deals have legitimate concerns in protecting those. 
